\title{
Primary production and nitrate uptake within the seasonal thermocline of a stratified shelf sea
}

\author{
Anna E. Hickman ${ }^{1,2, *}$, C. Mark Moore ${ }^{2}$, Jonathan Sharples $^{3}$, Michael I. Lucas ${ }^{4}$, \\ Gavin H. Tilstone ${ }^{5}$, Vladimir Krivtsov ${ }^{6}$, Patrick M. Holligan ${ }^{2}$ \\ ${ }^{1}$ Department of Biological Sciences, University of Essex, Wivenhoe Park, Colchester, CO4 3SQ, UK \\ ${ }^{2}$ Ocean and Earth Sciences, University of Southampton, National Oceanography Centre, Southampton, European Way, \\ Southampton, SO14 3ZH, UK \\ ${ }^{3}$ School of Environmental Sciences, University of Liverpool, and National Oceanography Centre, 4 Brownlow Street, \\ Liverpool, L69 3GP, UK \\ ${ }^{4}$ Department of Zoology, University of Cape Town, Rondebosch 7701, South Africa \\ ${ }^{5}$ Plymouth Marine Laboratory, Prospect Place, Plymouth, PL1 3DH, UK \\ ${ }^{6}$ School of the Built Environment, Herriot-Watt University, Edinburgh, EH14 4AS, UK
}

\begin{abstract}
Photosynthesis versus irradiance relationships were used to estimate primary production (PP) at a number of locations across the seasonally stratified Celtic Sea during summer in 2003 and 2005. A subsurface chlorophyll maximum (SCM) was ubiquitously located at the base of the seasonal thermocline on the nitracline. Average PP for the stratified waters was 170 to $390 \mathrm{mg}$ $\mathrm{C} \mathrm{m}^{-2} \mathrm{~d}^{-1}$, of which 40 to $50 \%$ occurred within the thermocline, the range reflecting cloudy or sunny conditions. Phytoplankton photosynthesis was light-limited at the SCM, resulting in PP in the thermocline being more sensitive to surface irradiance conditions than that in the surface mixed layer. During the stratified period, production fuelled by nitrate from below the thermocline was estimated to be $\sim 10$ to $19 \mathrm{~g} \mathrm{C} \mathrm{m}^{-2}$, around half that determined for the spring bloom. Comparison of carbon $\left({ }^{14} \mathrm{C}\right)$ fixation and nitrate $\left({ }^{15} \mathrm{NO}_{3}{ }^{-}\right)$uptake versus irradiance experiments revealed that the proportion of ${ }^{15} \mathrm{NO}_{3}{ }^{-}$uptake compared to ${ }^{14} \mathrm{C}$ fixed was higher at the SCM than in the upper part of the thermocline where nitrate was depleted. The proportion also decreased with increasing irradiance. Estimates of ${ }^{15} \mathrm{NO}_{3}{ }^{-}$and ${ }^{14} \mathrm{C}$ uptake, dissolved oxygen production and the potential vertical diffusive nitrate flux from below suggested that 'excess' nitrate is assimilated relative to photosynthetic carbon fixation in the thermocline, particularly under cloudy conditions.
\end{abstract}

KEY WORDS: Phytoplankton - Photosynthesis $\cdot$ Primary production $\cdot$ Carbon fixation $\cdot$ Nitrate uptake $\cdot$ Irradiance $\cdot$ Continental shelf $\cdot$ Celtic Sea

\section{INTRODUCTION}

Despite covering $<10 \%$ of the surface area of the oceans, shelf seas are considered to be highly productive regions contributing 15 to $30 \%$ of total oceanic primary production (PP; Muller-Karger et al. 2005). Since shelf seas are important regions for the global carbon cycle and support significant fisheries, there is a need to understand the biological and physical processes governing shelf sea PP. Here we focused on the
Celtic Sea, a region of the NW European shelf with relatively weak tides that becomes stratified during the summer months (Pingree et al. 1978, Sharples \& Holligan 2006) and which is representative of other shelf seas with similar physical characteristics such as the northern North Sea (Rodhe et al. 2006), the shelf regions of the Bay of Biscay (Lavin et al. 2006) and around New Zealand (Sharples et al. 2001a).

In the Celtic Sea, stratification develops in spring (April), triggering a phytoplankton bloom that de- 
pletes the surface mixed layer (SML) of nitrate (Pingree et al. 1976, Fasham et al. 1983). Throughout the summer months, the degree of seasonal stratification is determined by competition between buoyancy input from solar heating and mixing caused by tidally generated turbulence at the seabed and wind at the surface (Simpson \& Hunter 1974). Summer surface waters are relatively warm and nutrient depleted, with low concentrations of chlorophyll $a$ (chl $a_{i}$ Pingree et al. 1976, Joint \& Groom 2000). Low pigment standing stocks resulting from lack of nitrate in the SML hence permit light penetration to the thermocline, the depth of which is determined by physical processes. Consequently, a subsurface chlorophyll maximum (SCM) occurs within the seasonal thermocline as a result of phytoplankton growth at the nitracline and an increase in cellular chl $a$ by low-light acclimated cells (Holligan et al. 1984a,b, Moore et al. 2006, Hickman et al. 2009). Phytoplankton found within the SCM include largercelled forms, such as dinoflagellates, coccolithophores and small diatoms (Holligan et al. 1984a, Sharples et al. 2001b, Hickman et al. 2009) compared to the picoplankton that characterize the SML (Joint et al. 1986). Vertical changes in taxonomic composition are thought to reflect species selection across gradients in light and nutrient availability (Hickman et al. 2009). Beneath the thermocline and SCM, tidal turbulence maintains a bottom mixed layer (BML) of relatively cold water containing high concentrations of nutrients.

Maximum observed SCM chl a concentrations in the Celtic Sea range from $>50 \mathrm{mg} \mathrm{m}^{-3}$ close to tidal mixing fronts (Pingree et al. 1976, Sharples et al. $2001 \mathrm{~b}$ ) to values of $\sim 1 \mathrm{mg} \mathrm{m}^{-3}$ across the open shelf (Hickman et al. 2009). Away from the narrow frontal regions where PP can be around 5 times higher (Holligan et al. 1984b, Joint \& Groom 2000), PP in the seasonally stratified region of the Celtic Sea is estimated to be $\sim 100 \mathrm{~g} \mathrm{C} \mathrm{m}^{-2} \mathrm{yr}^{-1}$ between April and September (Joint \& Groom 2000) with daily rates of 100 to $600 \mathrm{mg} \mathrm{C} \mathrm{m}^{-2} \mathrm{~d}^{-1}$ in the summer months (Joint \& Pomroy 1983, Holligan et al. 1984b, Joint et al. 1986, Maranon et al. 2005). Given the lack of nitrate observed in the SML, the thermocline is likely to be the only significant site of nitrate-fuelled production ('new production', sensu Dugdale \& Goering 1967) in the stratified shelf waters during summer (Holligan et al. 1984b), with the BML acting as the source of nitrate (Sharples et al. 2001b).

Quantifying PP in the seasonal thermocline and determining the proportion that is fuelled by 'new' nitrate from the BML is crucial for understanding shelf sea biogeochemistry and, ultimately, global carbon sequestration via mechanisms such as the 'Continental Shelf Pump' (Tsunogai et al. 1999). The magnitude of new production in the seasonal thermocline also has important consequences for fisheries (Dickey-Collas et al. 1996, Heath \& Beare 2008) and potentially top predators whose distributions have been shown to correlate with the summer SCM (Scott et al. 2010). Consequently, understanding how physical forcing controls PP is necessary for predicting the ecosystem and biogeochemical responses to climate-driven variations in surface irradiance or water column stratification (Sharples et al. 2006). Further, the processes controlling primary and new production in the Celtic Sea are likely to be relevant to other stratified systems with SCMs, including the oligotrophic gyres (Painter et al. 2007).

Here we investigated the factors controlling primary and new production within the characteristic nutrient-stratified regime exhibited across the Celtic Sea during summer. Specifically we aimed to: (1) quantify PP at a number of locations in the Celtic Sea and determine how much of this production occurs within the thermocline, (2) identify the main factors controlling variability in the magnitude of PP, and (3) determine the proportion of PP in the thermocline that is fuelled by nitrate. The results are considered in terms of dynamic physical and biological processes acting within the thermocline. To our knowledge, this is the first attempt to measure PP in the thermocline across a broad region of the seasonally stratified Celtic Sea, capturing a range of physical conditions such as tidal mixing, bottom topography and incident irradiance.

\section{MATERIALS AND METHODS}

\section{Hydrography and water sampling}

Data were collected at a number of stations in the Celtic Sea (Fig. 1) during RRS 'James Clark Ross' cruise JR98 (24 July to 14 August 2003) and RRS 'Charles Darwin' cruise CD173 (15 July to 6 August 2005). Hereafter these 2 cruises will be referred to as CS2003 and CS2005, respectively. A Seabird 911 CTD and rosette system was fitted with a Chelsea Instruments Aquatracka MKIII chlorophyll fluorometer and $24 \times 201$ Niskin bottles. During CS2003, an undulating towed instrument (Seasoar) containing a CTD and fluorometer was also deployed, and was calibrated via CTD casts (see below). Nitrate concen- 

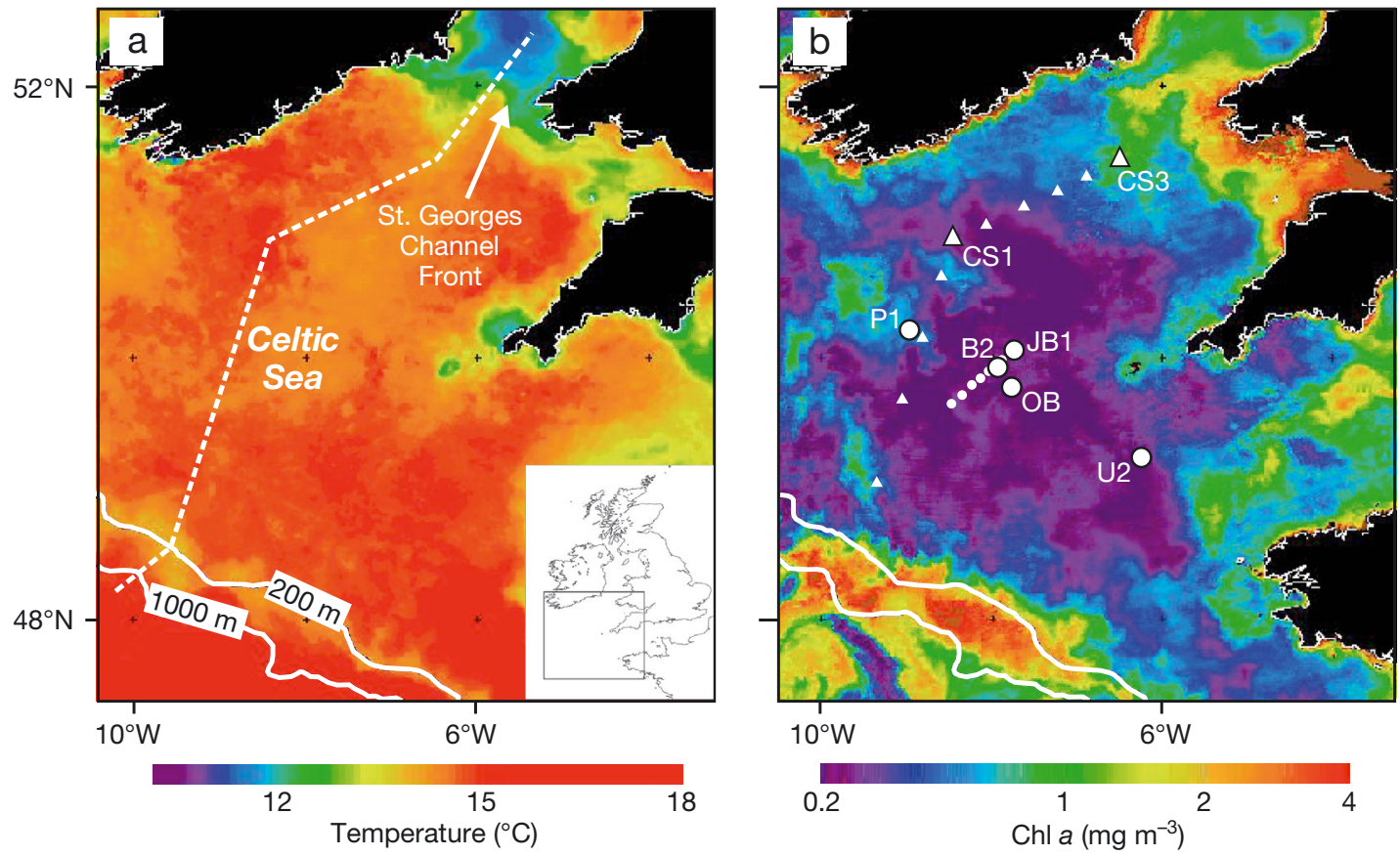

Fig. 1. Celtic Sea, showing sampling locations. (a) Surface temperature measured by AVHRR as a composite for 9 to 15 June 2005. The dotted line shows the Seasoar transect carried out during CS2003 travelling southwest to northeast. (b) Chlorophyll a ( $\mathrm{chl} \mathrm{a)} \mathrm{measured} \mathrm{via} \mathrm{SeaWIFS} \mathrm{as} \mathrm{a} \mathrm{composite} \mathrm{for} 9$ to 15 June 2005. Station positions during CS2003 (triangles) and CS2005 (circles) are shown, with larger symbols indicating locations where primary production (PP) estimates were made. White lines in (a) and (b) indicate the 200 and $1000 \mathrm{~m}$ depth contours

tration was measured on board by a standard colorimetric technique (Brewer \& Riley 1965) using a Skalar AAII-type autoanalyser. The limit of nitrate detection was $\sim 0.1 \mu \mathrm{M}$.

\section{Biological measurements}

Chl a was measured fluorometrically on-board, following methods of Welschmeyer (1994) from water samples filtered through Whatman GF/F filters. Fluorometrically derived $\mathrm{chl} a$ values were further scaled to those obtained from high-performance liquid chromatography (Hickman et al. 2009) and used to calibrate the CTD fluorometers. Measurements of phytoplankton light absorption were based on the filter pad technique (Bricaud \& Stramski 1990, Tassan \& Ferrari 1995) as described by Moore et al. (2006) and Hickman et al. (2009) for CS2003 and CS2005, respectively. Total particulate organic carbon (POC) and particulate organic nitrogen (PON) were obtained from water samples filtered onto ashdried GF/F filters, stored at $-80^{\circ} \mathrm{C}$ and subsequently analysed in the laboratory using a Thermo Finnegan Flash EA1112 elemental analyser (Poulton et al. 2006).

\section{Irradiance and primary production}

PP was estimated by combining measurements of the irradiance dependence of photosynthesis at each station and of spectrally resolved in situ photosynthetically available radiation (PAR) using methods similar to those of Tilstone et al. (2003) and Morel et al. (1996). PAR, measured as $E(z)\left(\mu \mathrm{E} \mathrm{m}^{-2} \mathrm{~s}^{-1}\right)$, which is the integral of irradiance $E(\lambda, z)$ between 400 and $700 \mathrm{~nm}$, was modeled empirically at each depth $(z)$ through the water column and for any given broadband PAR incident at the sea surface, $E_{\text {incident, }}$ using knowledge of (1) the transmittance of PAR through the sea surface, $\tau$ (dimensionless), (2) the PAR-normalised light spectrum just below the surface, $\overline{E(\lambda, 0)}$ $\left(\mu \mathrm{E} \mathrm{m} \mathrm{m}^{-2} \mathrm{~s}^{-1}\right)$, and (3) the light attenuation at each wavelength, $K_{\mathrm{d}}(\lambda, z)$, following

$$
\begin{aligned}
& E(\lambda, 0)=E_{\text {incident }} \cdot \tau \cdot \overline{E(\lambda, 0)} \\
& E(\lambda, z)=E(z-1) \cdot \mathrm{e}^{-K_{d}(\lambda, z) \cdot \mathrm{d} z}
\end{aligned}
$$

where $E(\lambda, 0)$ is the spectral irradiance just below the surface and $\mathrm{d} z=1 \mathrm{~m}$. Values for $\tau, \overline{E(\lambda, 0)}$ and $K_{\mathrm{d}}(\lambda, z)$ were derived from downwelling irradiance measurements made with a SATLANTIC in situ optics profiler at 7 wavelengths during CS2003 and 6 wavelengths 
during CS2005 (Moore et al. 2006, Hickman et al. 2009). Linear interpolation between measured wavelengths provided spectra at $1 \mathrm{~nm}$ resolution. A factor of 1.2 converted downwelling to scalar irradiance (Kirk 1994). $E(\lambda, 0)$ and $K_{\mathrm{d}}(\lambda, z)$ were derived from surface intercepts and gradients of the log-transformed irradiance profiles respectively for CS2003 and following Hickman et al. (2009) for CS2005. An average value of $\tau$ for each cruise was calculated from the ratio of PAR above the surface as recorded by the ship's meteorological package during the optics profiler deployment and PAR below the surface (Tilstone et al. 1999).

Standard short (2 to $4 \mathrm{~h}){ }^{14} \mathrm{C}$-uptake photosynthesis versus irradiance $(P$ versus $E)$ experiments were used to measure both absolute and chl a normalised $\mathrm{PP}$ and hence derive the chl a specific maximum light-saturated photosynthesis rate, $P_{\mathrm{m}}^{*}\left(\mathrm{mg} \mathrm{C} \mathrm{mg}{ }^{-1}\right.$ chl $a \mathrm{~h}^{-1}$ ) and the maximum light utilisation coefficient, $\alpha_{\text {insitu }}\left(\mathrm{mg} \mathrm{C} \mathrm{mg}{ }^{-1} \mathrm{chl} \mathrm{a} \mathrm{h}^{-1}\left[\mu \mathrm{E} \mathrm{m} \mathrm{m}^{-2} \mathrm{~s}^{-1}\right]^{-1}\right.$ ) (Jassby \& Platt 1976). Samples were collected at 2 depths during CS2003 (1 in the SML and 1 at the SCM) and 4 depths during CS2005 (2 in the SML, 1 in the upper thermocline and 1 in the lower thermocline at the SCM). Samples were collected before dawn and incubated in $73 \mathrm{ml}$ polycarbonate bottles in photosynthetrons at constant temperature corresponding to either the SML or SCM. Values of $\alpha_{\text {insitu }}$ and the

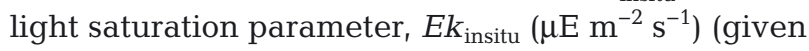
by $\left.P^{*}{ }_{\mathrm{m}} / \alpha_{\text {insitu }}\right)$ were spectrally corrected to the in situ irradiance at the sample depth according to the phytoplankton light absorption, $a^{*}(\lambda, z)$ (following Moore et al. 2006, who also provided a detailed analysis of phytoplankton photophysiology for cruise CS2003).

PP (given by $P[z]$ ) was then calculated at $1 \mathrm{~m}$ depth resolution from

$$
P(z)=\mathrm{Chl}_{\mathrm{CTD}}(z) \cdot P_{\mathrm{m}}^{*}(z) \cdot \tanh \left(\frac{E(z) \cdot \alpha(z)_{\text {insitu }}}{P^{*}{ }_{\mathrm{m}}(z)}\right)
$$

based on Jassby \& Platt (1976), where $P^{*}{ }_{\mathrm{m}}(z), \alpha(z)_{\text {insitu }}$ and $a^{*}(\lambda, z)$ required for the spectral correction were obtained via linear interpolation of measured parameter values between sample depths. For CS2003, parameter values obtained in the SML were assumed representative of that layer whilst those within the thermocline were obtained from a linear interpolation between SML values at the top of the thermocline and those at the $\mathrm{SCM} . \mathrm{Chl}_{\mathrm{CTD}}(z)$ was provided by calibrated CTD fluorescence profiles. Eqs. (1), (2) \& (3) thus allowed PP to be estimated from stationspecific physiological data and empirically modeled spectral irradiance for any chosen incident surface PAR.
Hourly PP profiles were calculated for the following daylight scenarios: (1) the recorded incident PAR during the day of sampling, (2) a representative sunny day (peak daytime irradiance $1880 \mu \mathrm{E} \mathrm{m}^{-2} \mathrm{~s}^{-1}$ ) and (3) a representative cloudy day (peak daytime irradiance $520 \mu \mathrm{E} \mathrm{m}^{-2} \mathrm{~s}^{-1}$ ). A full range of peak daytime irradiances spanning these values was observed during both cruises, with cloudy and sunny conditions sometimes occurring on consecutive days. We thus consider that the chosen range of surface incident irradiances represent realistic limits for PP on any given day.

Daily PP estimates were obtained by integrating hourly profiles over the photoperiod and through depth for both the SML and thermocline. The upper boundary of the thermocline was defined as the depth at which water density reached $0.05 \mathrm{~kg} \mathrm{~m}^{-3}$ above surface density. The lower boundary was calculated as the depth where density was $0.02 \mathrm{~kg} \mathrm{~m}^{-2}$ below that of the bottom density. For the minority of casts where the SML and BML were poorly defined by density, the thermocline boundaries were identified from the density profiles by eye, taking into consideration information from neighboring CTD casts (Hickman et al. 2009). The thermocline was further categorised into an upper region where nitrate concentrations were $<0.1 \mu \mathrm{M}$ (below the limit of instrument detection), and a lower region where concentrations were $>0.1 \mu \mathrm{M}$ (i.e. the nitracline). Given the very low mean light environment of the $\mathrm{BML}$, PP below the thermocline was considered to be negligible.

We briefly consider the implications of some of the assumptions made in the calculation of PP. Although no consistent pattern in the diel variability of $P$ versus $E$ parameters could be determined for either the SML or SCM (Moore et al. 2006), we estimate that neglecting diel variability may have potentially led to a $\sim 12 \%$ underestimation of daily PP. In contrast, from available data we calculated that the contribution of light absorption by non-photosynthetic carotenoids could have resulted in a potential overestimation of PP by 10\% (in agreement with Bouman et al. 2000). Our daily PP estimates neglected diurnal changes in chl a profiles but for stations with available data, this only accounted for an average variability in daily PP of $\sim 5 \%$ excluding the weakly stratified site CS3, and $\sim 15 \%$ when CS3 was included. We further acknowledge that our PP estimates based on short ( $2 \mathrm{~h}$ ) incubations will lie between net and gross photosynthesis (Williams 1993, Robinson et al. 2009, Halsey et al. 2010) and do not account for dissolved organic carbon release (Maranon et al. 2005). 


\section{Nitrate uptake}

At Stns CS3b, OB and B2a, nitrate uptake and carbon fixation versus irradiance experiments were carried out using ${ }^{15} \mathrm{NO}_{3}{ }^{-}$and ${ }^{13} \mathrm{C}$ stable isotope tracer techniques (Dugdale \& Goering 1967). ${ }^{15} \mathrm{NO}_{3}{ }^{-}$was added to seawater samples at $<10 \%$ of ambient nitrate concentration. Incubations were terminated by filtration through pre-ashed GF/F filters (Glibert \& Capone 1993). As will be shown later, photosynthesis-irradiance curves for ${ }^{13} \mathrm{C}$ and ${ }^{14} \mathrm{C}$ were highly comparable, demonstrating compatibility between the separate experiments despite larger (1 l) sample bottles and longer ( 3 to $5 \mathrm{~h}$ ) incubations for the stable isotope tracer experiments. We acknowledge that ${ }^{15} \mathrm{NO}_{3}{ }^{-}$uptake may have been overestimated for experiments where the ambient nitrate concentrations were below the limit of detection. To estimate daily ${ }^{15} \mathrm{NO}_{3}{ }^{-}$uptake, it was assumed that nitrate uptake continued in the dark (Cochlan et al. 1991) at a rate given by the intercept of the uptake versus irradiance curve.

\section{Dissolved oxygen concentration}

In situ dissolved oxygen concentration $\left(\mathrm{mg} \mathrm{l}^{-1}\right)$ was measured during CS2005 using a Seabird dissolved oxygen sensor mounted on the CTD frame and calibrated by water samples analysed using the Winkler technique. Oxygen saturation (\%) was calculated following Weiss (1970), and apparent oxygen utilisation (AOU) was calculated as the difference between the dissolved oxygen concentration and that of the theoretical saturation limit. Negative AOU values thus reflect super-saturation and positive values reflect under-saturation.

\section{RESULTS}

\section{Hydrography}

The structure of the seasonal pycnocline across the Celtic Sea (Fig. 2a; Sharples et al. 2001b) was determined by variability in temperature rather than salinity. Significant vertical gradients of salinity (e.g. a difference of $~ 0.5$ PSS-78 between the SML and BML) were observed only in the weakly stratified region close to the St. George's Channel tidal mixing front (Stn CS3). Hereafter, the terms thermocline and temperature are used interchangeably with pycnocline and density to describe the structure of the water column.
The water depth ranged from approximately $100 \mathrm{~m}$ at CS1 and CS3 to $150 \mathrm{~m}$ at B2 and JB1 (Table 1). The thermocline was $28 \pm 11 \mathrm{~m}$ broad (mean $\pm \mathrm{SD}, \mathrm{n}=$ 151) and typically had an upper boundary with the SML at $15 \pm 7 \mathrm{~m}(\mathrm{n}=151$; Table 1$)$. The thermocline shoaled towards the St. George's Channel front and was broader around the shelf edge (Fig. 2a). Chl a concentrations were low in the stratified surface waters (Figs. 1 \& 2a,c, Table 1), and an SCM was always present within the thermocline (Fig. 2a).

The standing stock of chl a integrated to a depth of $70 \mathrm{~m}$ ranged from 20 to $40 \mathrm{mg} \mathrm{m}^{-2}$ across the stratified shelf, lower than the values at the St. George's Channel front and the shelf edge (Fig. 2a,c). Part of the variability in integrated chl a could be attributed to increases over topographic banks, such as those at 180 to $200 \mathrm{~km}$ and 230 to $240 \mathrm{~km}$ along the Seasoar transect (Fig. 2a,c). The variability in integrated chl a was generally not reflected in surface concentrations (Fig. 2c).

About $75 \%$ of water-column-integrated chl a was located within the thermocline ( $76 \pm 12 \%)$. The mean chl a concentration at the SCM was $1.09 \pm 0.97 \mathrm{mg}$ $\mathrm{m}^{-3}(\mathrm{n}=98)$ with a median concentration of $0.84 \mathrm{mg}$ $\mathrm{m}^{-3}$, reflecting high values at a small number of stations (range 0.23 to $8.36 \mathrm{mg} \mathrm{m}^{-3}$ ). As was the case for the thermocline, the depth of the SCM varied across the shelf (Fig. 2a) and with time. For example, the temperature and chl a structure at B2 varied during the day and between visits at different stages of the spring-neap tidal cycle (Fig. 2d,e). The mean SCM depth across all stations was $30 \pm 8 \mathrm{~m}$ ( $\mathrm{n}=96$, Fig. 2a, Table 1).

The vertical distribution of chl $a$ within the water column was variable relative to depth (Fig. 2a, see also Fig. 6) but showed a consistent pattern in relation to density (Figs. 2b \& 3 ). In general, the profile for chl a was asymmetric with respect to the density gradient, with the SCM located near the base of the pycnocline at an average density value of $\sim 1026.6 \pm$ $0.3 \mathrm{~kg} \mathrm{~m}^{-3}(\mathrm{n}=95)$. This pattern of vertical distribution was persistent at each station over time, and was similar between stations (Figs. 2b \& 3).

Nitrate concentrations ranged from $\sim 7 \pm 1.0 \mu \mathrm{M}$ in the BML $(\mathrm{n}=94)$ to below the limit of instrument detection $(\sim 0.1 \mu \mathrm{M})$ in the upper thermocline and SML (Fig. 3). The nitracline and thermocline were thus de-coupled, the vertical extent of the nitrate gradient being less than that of the thermocline. The SCM was typically located in the lower thermocline at a nitrate concentration of 1 to $2 \mu \mathrm{M}$ (Fig. 3). The SCM and nitracline were occasionally observed higher up in the density gradient, for example at 

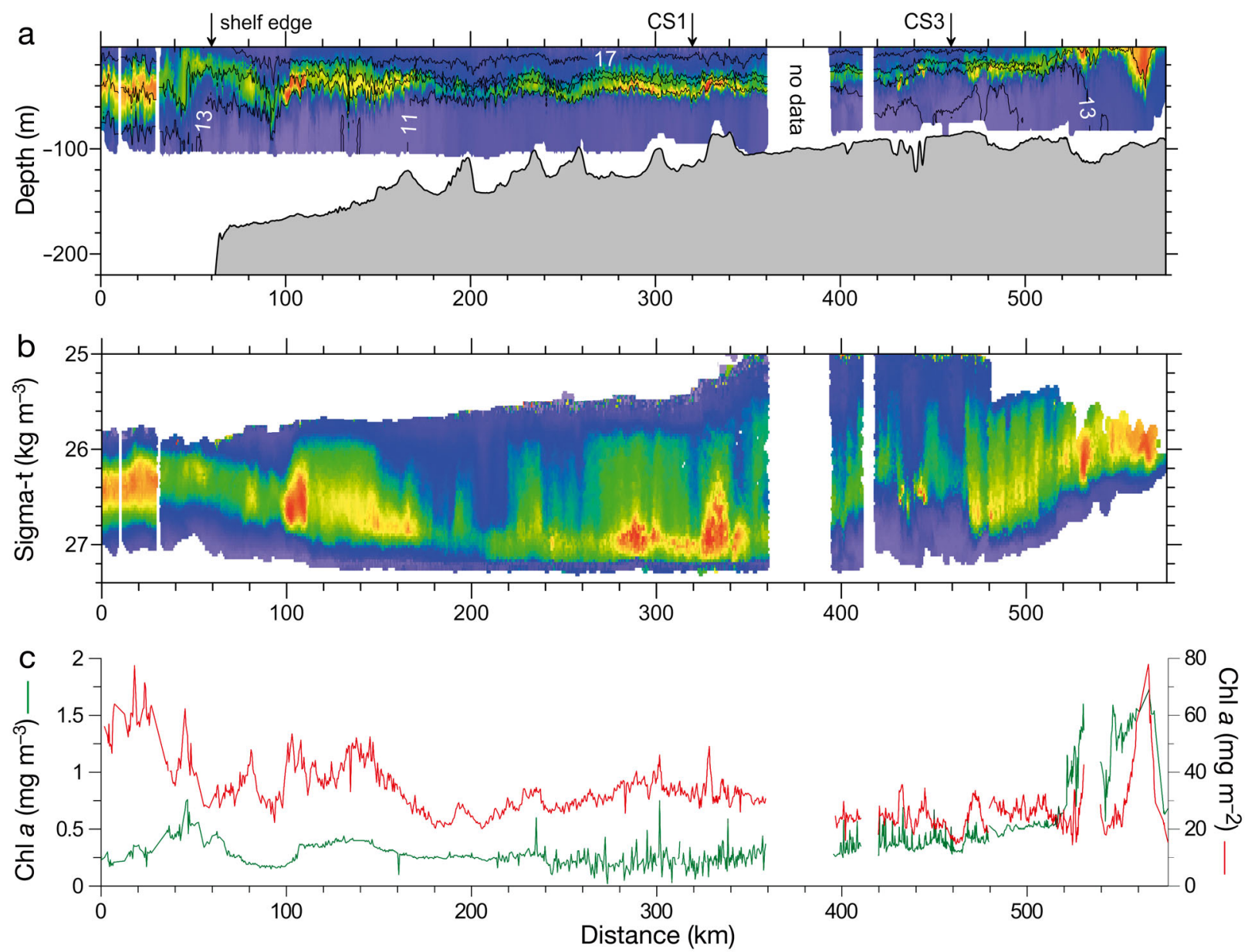

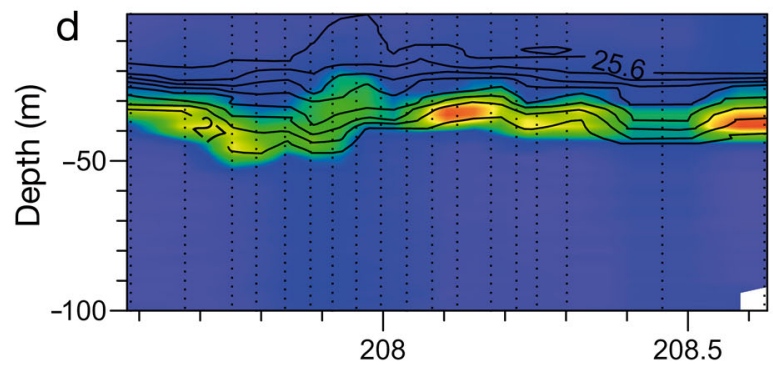

Day of Year

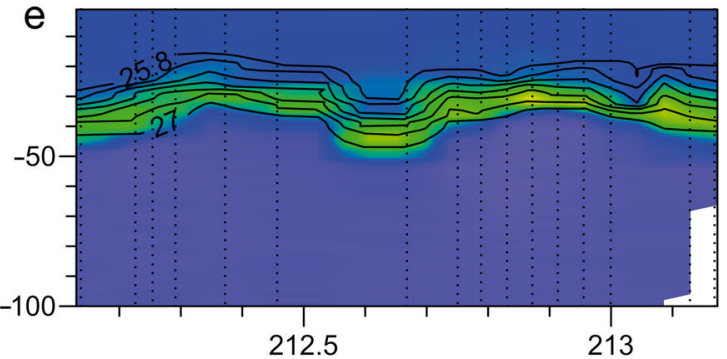

Day of Year

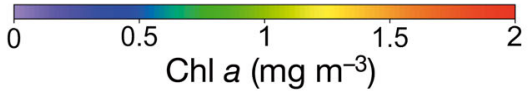

Fig. 2. (a-c) Chlorophyll a ( $\mathrm{chl}$ a) from Seasoar transect and (d,e) CTD timeseries at Stn B2 (see Fig. 1). Chl a plotted against (a) depth and (b) density (as sigma-t), where contour lines are temperature $\left({ }^{\circ} \mathrm{C}\right)$. (c) Chl $a$ at the surface (green line) and integrated to $70 \mathrm{~m}$ (red line). Time-series of chl $\mathrm{a}$ at Stn B2 (d) $3 \mathrm{~d}$ before neap tide and (e) $1 \mathrm{~d}$ following neap tide, where solid lines are density (sigma-t, $\mathrm{kg} \mathrm{m}^{-3}$ ). Note that in (d) and (e), the chl a signature reflects temporal variability at B2 as well as advection of water past the ship

Stn B2a, which was on the slope of Jones' Bank, and more persistently during neap tides at CS3a which was close to the St. Georges Channel front (Fig. 3).

The peak daytime irradiance incident at the sea surface ranged from 610 to $2000 \mu \mathrm{E} \mathrm{m}^{-2} \mathrm{~s}^{-1}$ during CS2003 and from 520 to $1960 \mu \mathrm{E} \mathrm{m} \mathrm{m}^{-2} \mathrm{~s}^{-1}$ during
CS2005, with an average peak daytime irradiance of $1400 \mu \mathrm{E} \mathrm{m}^{-2} \mathrm{~s}^{-1}$ during both cruises. At the depth of the SCM peak, PAR was $6 \pm 5 \%$ of that at the surface (Table 1, Hickman et al. 2009), depending on the thermocline depth and light attenuation through the SML. 
Table 1. Properties and variability of water column structure and chlorophyll a ( $\mathrm{chl} a)$ characteristics at stations where primary production (PP) was estimated (see Fig. 1). Locations were typically sampled throughout a 25 h period (except U2, P1 and JB1, which were only sampled before dawn). Layer-integrated chl a was obtained from the (calibrated) CTD fluorescence profiles. SML: surface mixed layer, Therm: thermocline, SCM: subsurface chlorophyll maximum. ' $a$ ' and ' $b$ ' identify different visits to the same location. Values are means \pm SD. Water depths vary with the tide and bathymetry in the vicinity of the sampling station

\begin{tabular}{|c|c|c|c|c|c|c|c|}
\hline \multirow[t]{2}{*}{ Station } & \multirow[t]{2}{*}{$\mathrm{n}$} & \multirow[t]{2}{*}{$\begin{array}{l}\text { Water depth } \\
\qquad(\mathrm{m})\end{array}$} & \multicolumn{2}{|c|}{$\begin{array}{l}\text { Layer thickness } \\
\text { (m) }\end{array}$} & \multicolumn{2}{|c|}{$\begin{array}{l}\text { Layer-integrated } \\
\text { chl } a\left(\mathrm{mg} \mathrm{m}^{-2}\right)\end{array}$} & \multirow[t]{2}{*}{$\begin{array}{l}\text { Irradiance at } \\
\text { SCM peak }(\%)\end{array}$} \\
\hline & & & SML & Therm & SML & Therm & \\
\hline $\mathrm{B} 2 \mathrm{a}$ & 18 & $122 \pm 10$ & $16 \pm 3$ & $30 \pm 6$ & $5 \pm 2$ & $20 \pm 5$ & $5 \pm 2$ \\
\hline $\mathrm{B} 2 \mathrm{~b}$ & 16 & $153 \pm 10$ & $21 \pm 5$ & $21 \pm 4$ & $9 \pm 2$ & $14 \pm 3$ & $5 \pm 2$ \\
\hline JB1a & 1 & 150 & 18 & 31 & 5 & 35 & 5 \\
\hline $\mathrm{JB} 1 \mathrm{~b}$ & 1 & 158 & 23 & 15 & 10 & 11 & 9 \\
\hline $\mathrm{OB}$ & 15 & $118 \pm 13$ & $18 \pm 5$ & $22 \pm 3$ & $7 \pm 2$ & $14 \pm 2$ & $5 \pm 2$ \\
\hline P1 & 3 & $132 \pm 2$ & $19 \pm 4$ & $36 \pm 3$ & $7 \pm 2$ & $22 \pm 4$ & $5 \pm 3$ \\
\hline $\mathrm{U} 2$ & 1 & 119 & 22 & 7 & 5 & 6 & 13 \\
\hline CS1 & 16 & $97 \pm 1$ & $23 \pm 3$ & $23 \pm 6$ & $5 \pm 1$ & $12 \pm 4$ & $3 \pm 0$ \\
\hline CS3a & 21 & $98 \pm 1$ & $8 \pm 3$ & $25 \pm 5$ & $4 \pm 2$ & $18 \pm 3$ & $9 \pm 6$ \\
\hline CS3b & 21 & $98 \pm 1$ & $5 \pm 2$ & $39 \pm 13$ & $2 \pm 1$ & $18 \pm 9$ & $8 \pm 4$ \\
\hline All shelf & 151 & $122 \pm 31^{\mathrm{a}}$ & $15 \pm 7$ & $28 \pm 11$ & $6 \pm 3$ & $17 \pm 7$ & $6 \pm 5$ \\
\hline
\end{tabular}

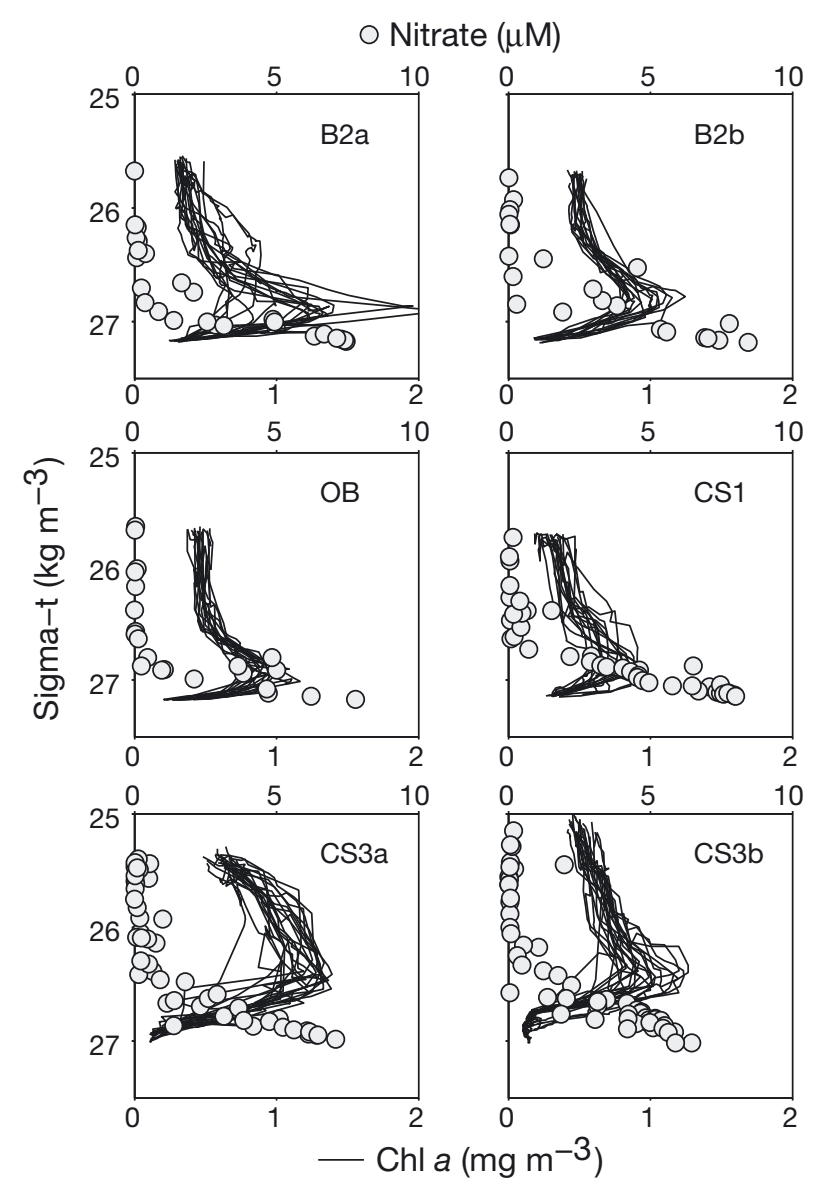

Fig. 3. Vertical profiles of chlorophyll a $(\mathrm{chl}$ a) from calibrated CTD fluorescence profiles (solid lines), and nitrate concentrations (circles) within the thermocline plotted against density (sigma-t), during $24 \mathrm{~h}$ occupations of selected stations. 'a' and 'b' identify different visits to the same location

\section{Phytoplankton photophysiology and production}

Measurements of the phytoplankton physiological parameters are summarised in Figs. 4 \& 5. Values of $E k_{\text {insitu }}$ decreased with depth, with $71 \%$ of the variability explained by $P^{*}$ m compared to only $11 \%$ by $\alpha_{\text {insitu }}\left(\mathrm{n}=55\right.$; Fig. 4). For the SML, $E k_{\text {insitu }}$ was similar to the mean irradiance experienced during the previous day. In contrast, for the thermocline, $E k_{\text {insitu }}$ was consistently higher than the mean irradiance (Fig. 5a), instead being similar to the maximum irradiance experienced the previous day (Fig. 5b). It follows that during most of the day, photosynthetic rates for phytoplankton in the SML were close to the maximum $\left(P_{\mathrm{m}}^{*}\right)$, whilst in the thermocline, rates were sub-optimal and corresponded to the light-limited slope $\left(\alpha_{\text {insitu }}\right)$ region of the $P$ versus $E$ curve.

PP was estimated at a number of stations across the open shelf (Fig. 1) that were representative of the range of conditions (water depth, the spring-neap tidal cycle, recent wind mixing and other factors) affecting the depth and form of the pycnocline. Profiles of PP resembled the chl a structure (Fig. 6), with additional influences from the in situ irradiance and the photophysiological state of the phytoplankton community. A distinct subsurface maximum in PP occurred only when surface irradiance and/or chl a concentration at the SCM were relatively high (Fig. 6).

When estimated for the irradiance conditions experienced on the day of sampling, water column integrated PP for the stratified shelf ranged from 140 to $460 \mathrm{mg} \mathrm{C} \mathrm{m} \mathrm{d}^{-1}$. Highest values were found at JB1a, close to Jones' Bank, and the lowest values at 

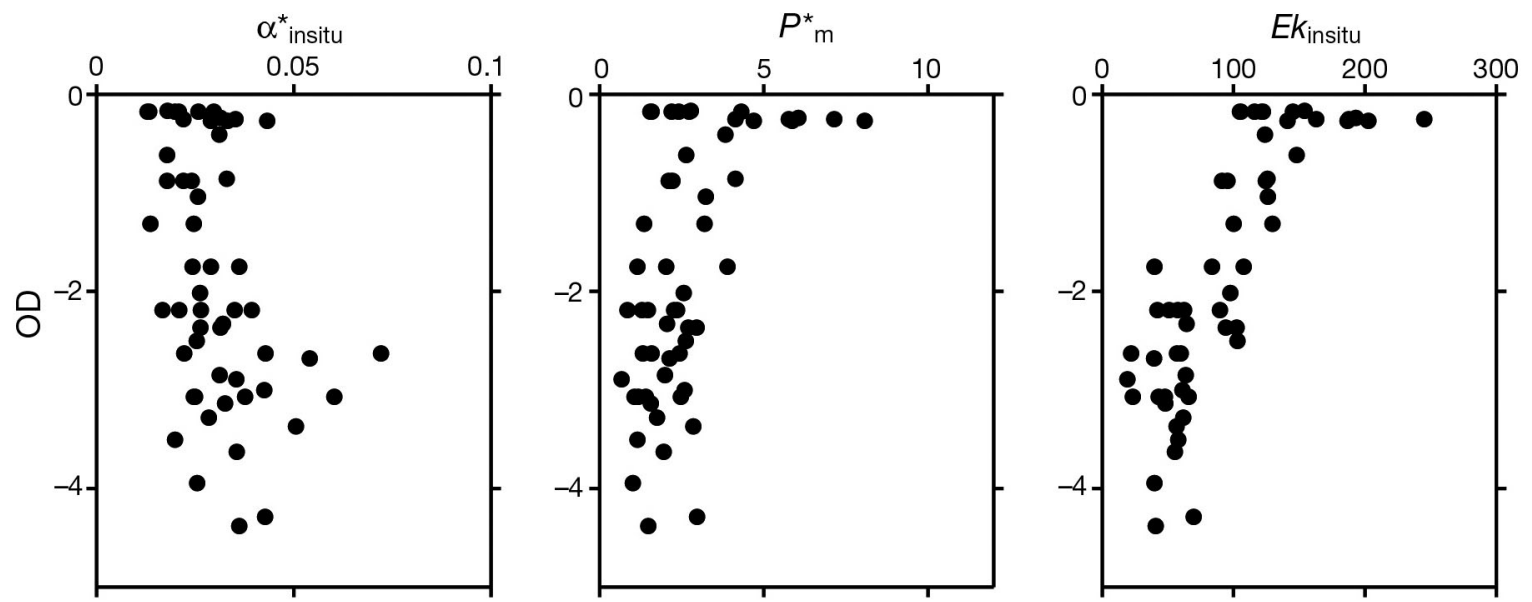

Fig. 4. Photophysiological parameters obtained from ${ }^{14} \mathrm{C}$-uptake photosynthesis versus irradiance $(P$ vs. $E)$ experiments

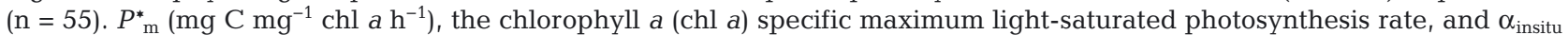
( $\mathrm{mg} \mathrm{C} \mathrm{mg}^{-1} \mathrm{chl} \mathrm{h} \mathrm{h}^{-1}\left[\mu \mathrm{E} \mathrm{m}^{-2} \mathrm{~s}^{-1}\right]^{-1}$ ), the maximum light utilisation coefficient, reflect the maximum and initial slope of the chl $a$

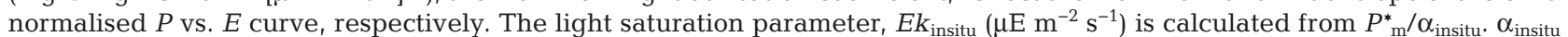
and $E k_{\text {insitu }}$ are spectrally corrected to the in situ irradiance at the sample depth (following methods of Moore et al. 2006). OD is optical depth, obtained from the sample depth $(\mathrm{m}) \times K_{\mathrm{d}}(\mathrm{PAR})$ where $K_{\mathrm{d}}(\mathrm{PAR})$ is the vertical attenuation coefficient for photosynthetically available radiation

B2a on the edge of Jones' Bank and at CS1. Watercolumn-integrated PP was significantly correlated to mean daily irradiance on the day of sampling $\left(r^{2}=0.71, p=0.002, n=10\right)$, but not to any other variable, including the surface $(2 \mathrm{~m}) \mathrm{chl}$ a concentration (Fig. 7a).

When standardised for irradiance, the average water-column-integrated daily PP for the stratified shelf was 174 (range 113 to 248) and 386 (range 252 to 490$) \mathrm{mg} \mathrm{C} \mathrm{m}^{-2} \mathrm{~d}^{-1}$ for cloudy and sunny conditions, respectively (Table 2). The contrast in incident daily irradiance between cloudy and sunny conditions thus accounted for a greater range in PP than was observed between locations (Fig. 7b). Further, when standardised for irradiance, the relationship between PP estimates and surface chl a was stronger than when PP was estimated for irradiance levels on the day of sampling (Fig. 7a,b), but the relationships remained insignificant ( $p>0.05)$. Even when standardised for irradiance, no significant correlations could be found between estimated total water-column-integrated PP and factors such as physiological ( $P$ versus $E$ ) parameters, stage of spring-neap tidal cycle, relative irradiance depth of the SCM or even layer-integrated PP for the SML or thermocline. There was no obvious regional pattern to PP estimates, for example with relation to topography.

When the SML and thermocline layers were considered separately, a significant correlation between layer-integrated PP and layer-integrated chl a was found for both the SML and thermocline (Fig. $7 \mathrm{c}, \mathrm{d}$ ). SML-integrated PP was significantly correlated to SML thickness during both cloudy and sunny condi-
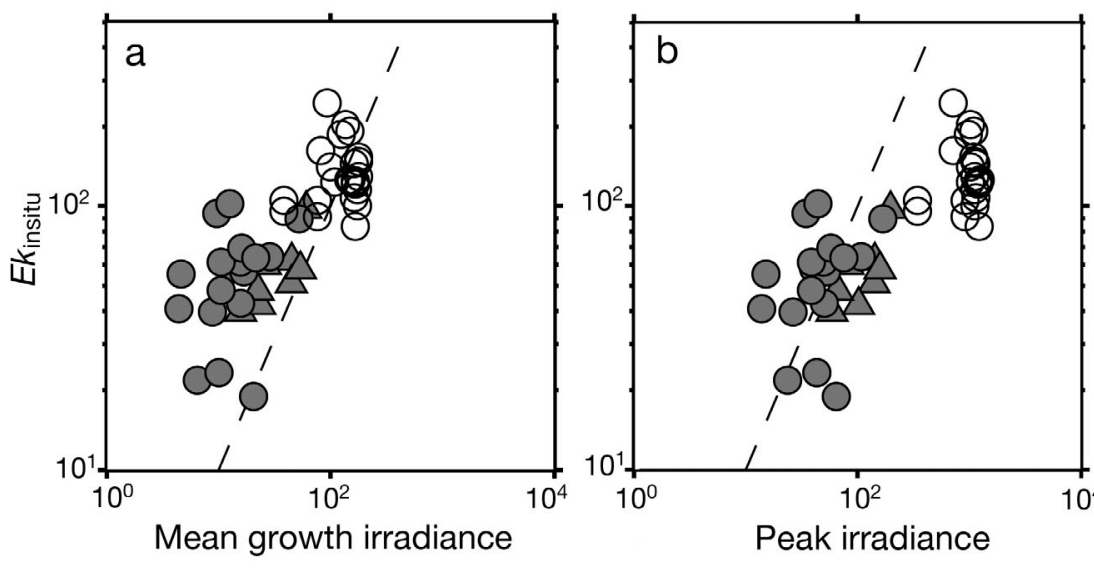

Fig. 5. Light saturation parameter $\left(E k_{\text {insitu }} \mu \mathrm{E} \mathrm{m^{-2 }}\right.$ $\mathrm{s}^{-1}$ ) plotted against (a) mean growth irradiance and (b) peak irradiance $\left(\mu \mathrm{E} \mathrm{m}^{-2} \mathrm{~s}^{-1}\right)$. Open and grey circles are samples collected in the surface mixed layer (SML) and subsurface chlorophyll maximum (SCM), respectively. Grey triangles denote samples collected in the upper thermocline during CS2005. Mean growth irradiance was estimated as the mean irradiance experienced during the previous $24 \mathrm{~h}$ period (for samples collected in the SML, the mean growth irradiance was that averaged through the SML). Peak irradiance was the maximum irradiance recorded on the previous day (for samples in the SML, the peak irradiance was assumed to be that just below the surface). The dashed lines are 1:1 

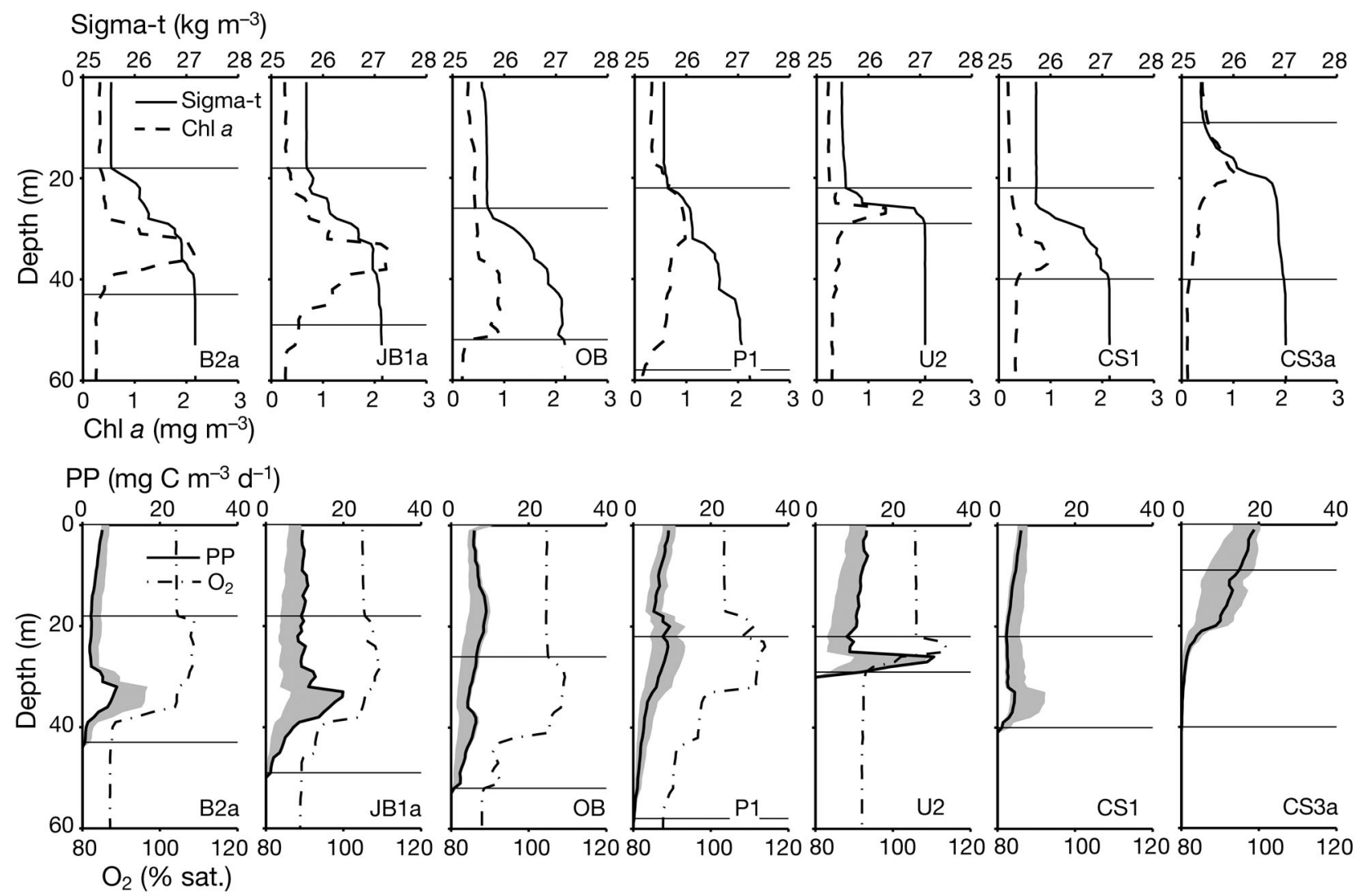

Fig. 6. Top panels: vertical profiles of chlorophyll a ( $\mathrm{chl} \mathrm{a)} \mathrm{and} \mathrm{density} \mathrm{(sigma-t)} \mathrm{for} \mathrm{selected} \mathrm{stations.} \mathrm{Bottom} \mathrm{panels:} \mathrm{vertical}$ profiles of primary production (PP) estimated for the irradiance recorded on the day of sampling (solid lines) and dissolved oxygen saturation (dotted lines) for selected stations. Shaded region indicates the range in PP when estimated for cloudy and sunny conditions. Horizontal grey lines indicate the top and bottom boundaries of the thermocline (see 'Materials and methods'). Dissolved oxygen profiles were only available during cruise CS2005. ' $a$ ' indicates the first visit to the location

tions, but only when neglecting data from the near frontal CS3 station where the top of the thermocline was poorly defined (cloudy: $\mathrm{r}^{2}=0.56, \mathrm{p}=0.03, \mathrm{n}=8$; sunny: $\mathrm{r}^{2}=0.59, \mathrm{p}=0.03, \mathrm{n}=8$ ). For cloudy conditions, SML-integrated PP was correlated to $\mathrm{P}^{*} \mathrm{~m} \times$ chl $a$ at $2 \mathrm{~m}\left(\mathrm{r}^{2}=0.78, \mathrm{p}=0.004, \mathrm{n}=8\right)$ when data from CS3 were excluded (Fig. 7e). Thermoclineintegrated PP was significantly correlated to thermocline thickness during sunny but not cloudy conditions $\left(\mathrm{r}^{2}=0.46, \mathrm{p}=0.03, \mathrm{n}=10\right)$. For cloudy conditions, thermocline-integrated PP was significantly correlated to the product of $\alpha_{\text {insitu }} \times \operatorname{chl} a$ at the SCM $\left(\mathrm{r}^{2}=\right.$ 0.70, $p=0.003, n=10$; Fig. 7f).

The thermocline contributed between 24 and $65 \%$ to water-column-integrated PP with values for individual stations about $10 \%$ higher under sunny compared to cloudy conditions (Table 2, Fig. 8). On average for all stations, the thermocline contributed 40 to $50 \%$ to water-column-integrated $\mathrm{PP}$, the range reflecting incident daily irradiance. For both cloudy and sunny conditions, the contribution of the thermo- cline to total water column PP was significantly correlated to thermocline-integrated chl $a\left(\mathrm{r}^{2}=0.35, \mathrm{p}=\right.$ 0.07 and $r^{2}=0.54, p=0.02$ both $n=10$, for cloudy and sunny conditions, respectively).

\section{Nitrate uptake and oxygen production}

The dependence of ${ }^{15} \mathrm{NO}_{3}^{-}$uptake on irradiance was measured for water samples from the SCM at Stns CS3b and OB and from the upper thermocline at OB and B2a. All experiments revealed a light-dependent response for ${ }^{15} \mathrm{NO}_{3}{ }^{-}$uptake that differed from that for photosynthetic ${ }^{14} \mathrm{C}$ and ${ }^{13} \mathrm{C}$ fixation, as illustrated by results for Stn CS3b (Fig. 9a). When interpolated over $24 \mathrm{~h}$ for the representative cloudy and sunny conditions, daily nitrate uptake rates at the SCM ranged from 77 to $97 \mu \mathrm{mol} \mathrm{N} \mathrm{m}{ }^{-3} \mathrm{~d}^{-1}$ at site OB and 99 to $130 \mu \mathrm{mol} \mathrm{N} \mathrm{m}{ }^{-3} \mathrm{~d}^{-1}$ at CS3b. Estimated rates were lower in the upper thermocline (11 to $14 \mu \mathrm{mol} \mathrm{N} \mathrm{m}{ }^{-3} \mathrm{~d}^{-1}$ at $\mathrm{OB}$ and 19 to $28 \mu \mathrm{mol} \mathrm{N} \mathrm{m}{ }^{-3} \mathrm{~d}^{-1}$ 

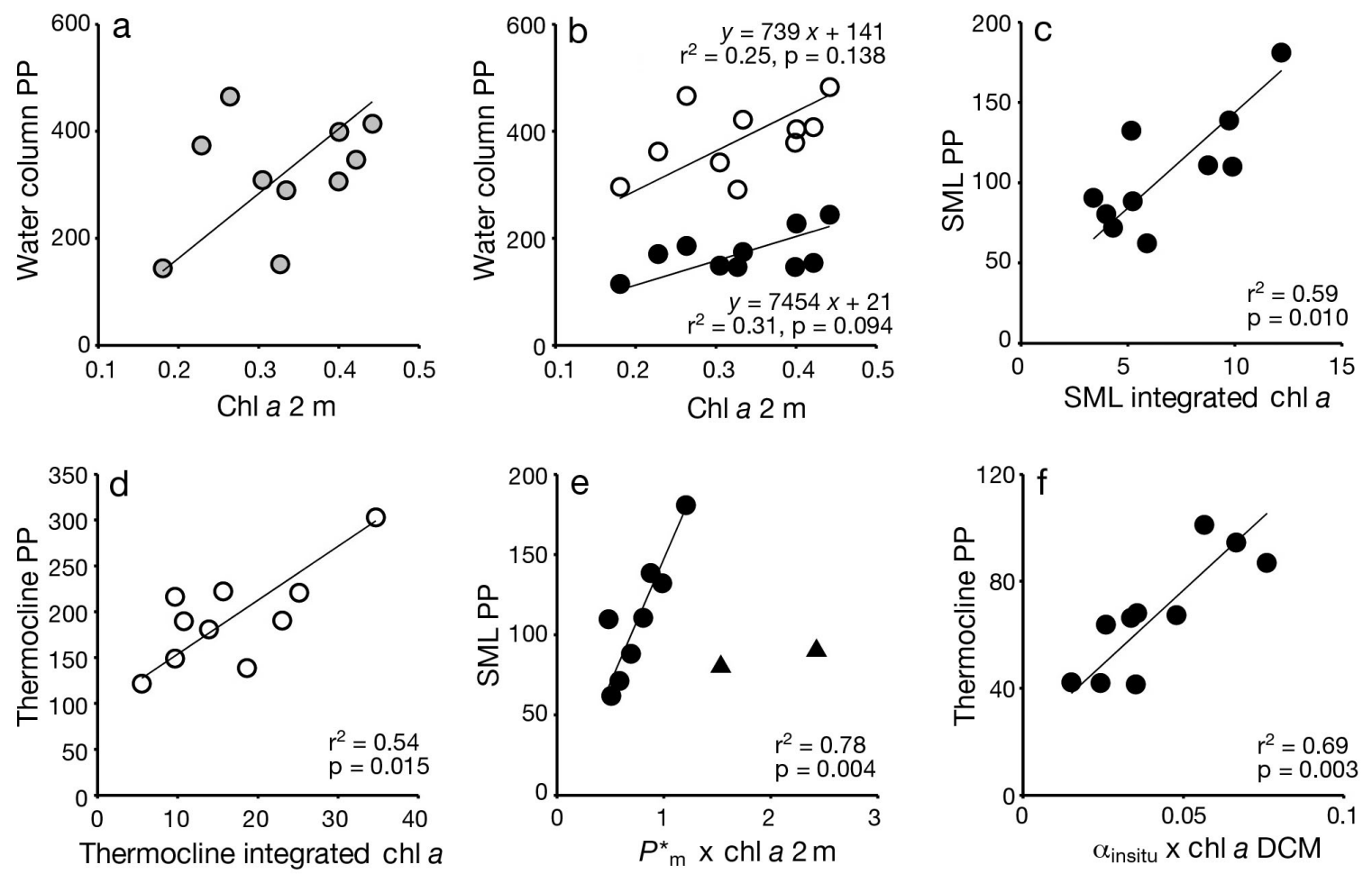

Fig. 7. Vertically integrated primary production (PP) values against other parameters: (a) water column-integrated daily PP

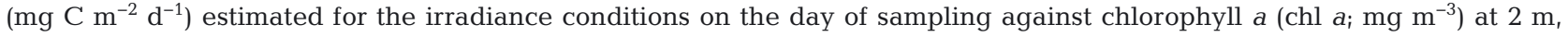
(b) water-column-integrated PP estimated for cloudy (solid symbols) and sunny (open symbols) conditions against chl a at $2 \mathrm{~m}$, (c) PP integrated through the surface mixed layer (SML) against integrated chl a within the SML, (d) PP integrated through the thermocline against integrated chl a within the thermocline, (e) PP integrated through the SML against the product of chl a concentration at $2 \mathrm{~m}$ and the maximum photosynthetic rate $P^{*}{ }_{\mathrm{m}}\left(\mathrm{mg} \mathrm{C} \mathrm{mg} \mathrm{mg}^{-1} \mathrm{ch} \mathrm{h}{ }^{-1}\right)$, and (f) PP integrated through the thermocline against the product of chl a concentration at the subsurface chlorophyll maximum (SCM) peak and $\alpha_{\text {insitu }}$ the maximum light utilisation coefficient $\left(\mathrm{mg} \mathrm{C} \mathrm{mg}^{-1} \mathrm{chl} \mathrm{a} \mathrm{h}^{-1}\left[\mu \mathrm{E} \mathrm{m}^{-2} \mathrm{~s}^{-1}\right]^{-1}\right)$. In all panels, solid circles indicate PP as estimated for the cloudy day and open symbols for the representative sunny day. In (f), the triangles identify CS3 where the thermocline boundaries were poorly defined, and these data were not used in the regression analysis. Statistics shown are results of model II regression

at B2a) where irradiance was higher, and chl $a$ and ambient nitrate concentrations were lower.

Higher irradiances led to marked increases in the estimated ${ }^{14} \mathrm{C}^{15} \mathrm{NO}_{3}{ }^{-}$uptake ratios (Fig. 9b). Daily ${ }^{14} \mathrm{C}^{15} \mathrm{NO}_{3}{ }^{-}$uptake ratios were significantly lower for the $\mathrm{SCM}\left(\mathrm{NO}_{3}>0.1 \mu \mathrm{M}\right)$ than for the upper thermocline $\left(\mathrm{NO}_{3}<0.1 \mu \mathrm{M}\right)$. Specifically, estimated daily mean ${ }^{14} \mathrm{C}^{15} \mathrm{NO}_{3}{ }^{-}$uptake ratios were 1.3 to 3.6 and 2.1 to $5.4 \mathrm{~mol}: \mathrm{mol}$ for the SCM at Stns OB and CS3b, respectively, compared to 31.8 to 64.1 and 8.0 to $11.0 \mathrm{~mol}: \mathrm{mol}$ in the upper thermocline at Stns OB and B2a, with upper and lower values in each case corresponding to assumed cloudy and sunny conditions. Thus a 4-fold increase in daily irradiance caused a 3-fold increase in the ${ }^{14} \mathrm{C}^{15} \mathrm{NO}_{3}{ }^{-}$uptake ratio at the SCM and a 2 -fold increase in the upper thermocline, with an 8-fold difference in the mean ratio between the lower and upper thermocline. Despite the wide variations in the ${ }^{14} \mathrm{C}^{15} \mathrm{NO}_{3}{ }^{-}$uptake ratio, the mean total POC:PON was $6.3 \pm 1.1$ (mol: mol, $n=4)$, close to the canonical Redfield $C: N$ value of 6.6 (Redfield 1934). Cruise mean particulate POC: PON was $7.5 \pm 0.6,6.9 \pm 0.5$ and $6.5 \pm 0.4(\mathrm{~mol}: \mathrm{mol})$ for the surface $(\sim 2 \mathrm{~m})$, upper thermocline and SCM, respectively (CS2005 only, $\mathrm{n}=7$ for each depth); POC:PON at the surface and SCM were significantly different (with $95 \%$ confidence) according to 1 -way analysis of variance.

Subsurface maxima in dissolved oxygen saturation were present in the upper part of the thermocline (Fig. 6) as observed for other regions of the NW European shelf seas (Richardson et al. 2000). Oxygen saturation levels were $104 \pm 1.0 \%(\mathrm{n}=79)$ in the SML and $88 \pm 0.8 \%(\mathrm{n}=79)$ in the $\mathrm{BML}$, with subsurface maxima values up to $109 \pm 4.3 \%(\mathrm{n}=79)$. The degree of maximum oxygen super-saturation was weakly correlated with chl a concentration at the $\mathrm{SCM}\left(\mathrm{r}^{2}=\right.$ $0.53, \mathrm{n}=79$ ), with relationships between these 2 para- 
Table 2. Ranges in the water column (WC)-integrated primary production (PP) values for the surface mixed layer (SML) and the thermocline for cloudy and sunny irradiance conditions. ' $a$ ' and ' $b$ ' identify different visits to the same location

\begin{tabular}{|lcccl|}
\hline & \multicolumn{3}{c}{ PP $\left(\mathrm{mg} \mathrm{C} \mathrm{m}^{-2} \mathrm{~d}^{-1}\right)$} & \multirow{2}{*}{ Tide } \\
\cline { 2 - 4 } Station & SML & Thermocline & Total WC & \\
\hline B2a & $62-105$ & $87-147$ & $149-252$ & Neap - 3 d \\
B2b & $181-309$ & $67-181$ & $248-490$ & Neap + 1 d \\
JB1a & $88-173$ & $101-303$ & $189-476$ & Spring - 3 d \\
JB1b & $139-222$ & $95-189$ & $234-411$ & Neap - 1 d \\
OB & $110-211$ & $42-138$ & $152-349$ & Neap + 3 d \\
P1 & $111-212$ & $68-220$ & $179-432$ & Neap \\
U2 & $132-249$ & $42-122$ & $174-371$ & Spring -3 d \\
CS1 & $71-148$ & $42-149$ & $113-297$ & Spring \\
CS3a & $80-157$ & $66-222$ & $146-379$ & Neap \\
CS3b & $90-191$ & $64-216$ & $154-407$ & Neap + 3 d \\
All shelf & $106-198$ & $67-189$ & $174-386$ & \\
\hline
\end{tabular}

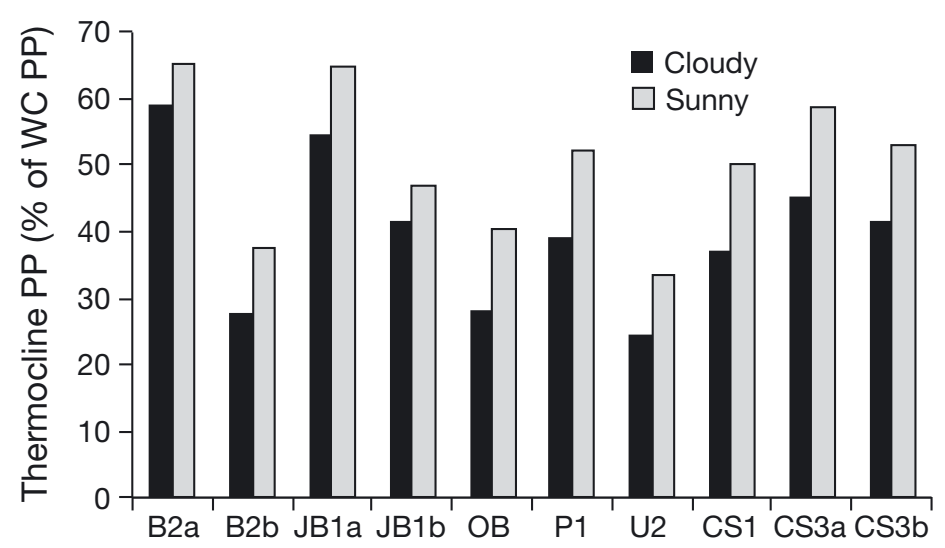

Fig. 8. Percentage contribution of primary production (PP) in the thermocline to the total water column (WC) production for all available locations meters being stronger when data from individual stations were considered separately.

For the lower thermocline where nitrate concentrations were above the limit of instrument detection $(>0.1 \mu \mathrm{M})$, concentrations of nitrate co-varied with AOU (Fig. 10). Outliers to this trend occurred at Stns U2 and P1, which exhibited narrower (U2) and broader (P1) thermoclines than elsewhere on the shelf (Figs. 6 \& 10). At P1, outliers were due to anomalously low values of nitrate at the base of the thermocline on more than 1 CTD cast. At U2, very low AOU (around $-65 \mu \mathrm{M}$ ) was associated with high chl a concentrations (up to $8.4 \mathrm{mg}$ $\mathrm{m}^{-3}$ ) at the SCM. The slope of the regression between AOU and nitrate concentration was on average 8.3 (Fig. 10); since nitrate concentration and oxygen saturation in the BML were relatively consistent across the shelf, variations in the slope probably reflected peak oxygen concentration values which co-varied with chl a maxima.

\section{DISCUSSION}

\section{Distribution of chl a}

During the mid-summers of 2003 and 2005, the vertical distribution of chl $a$ in the Celtic Sea was characterized by a subsur-
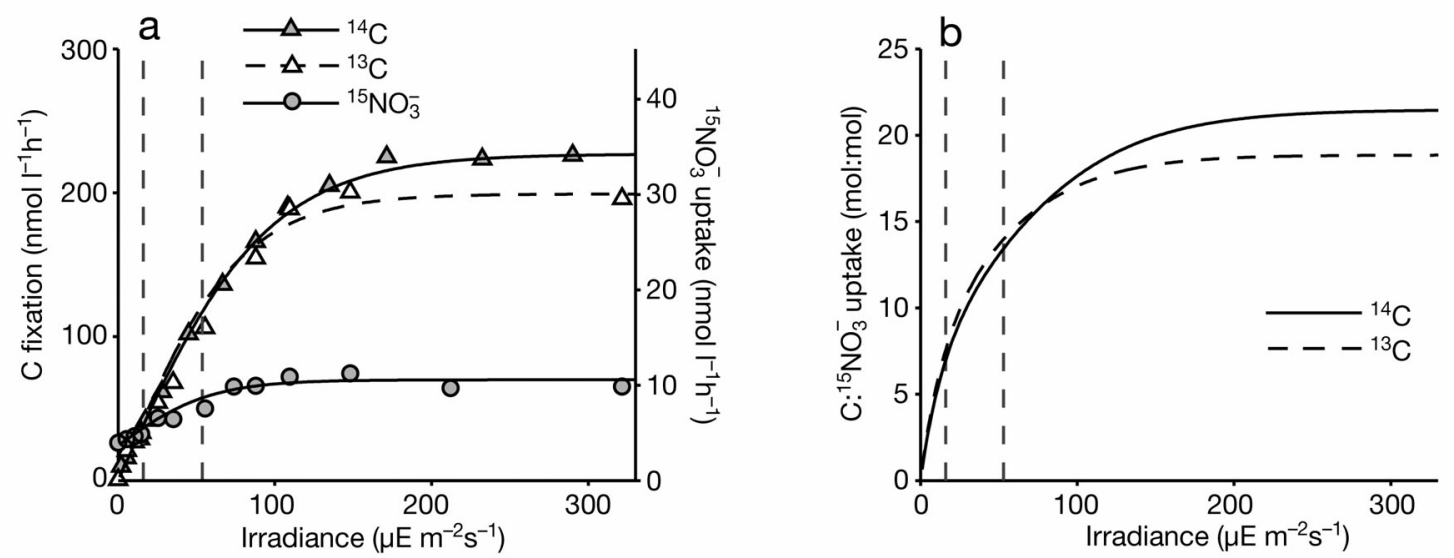

Fig. 9. Plots of ${ }^{14} \mathrm{C}$ photosynthesis, ${ }^{13} \mathrm{C}$ photosynthesis and ${ }^{15} \mathrm{NO}_{3}^{-}$uptake against irradiance for the subsurface chlorophyll maximum (SCM) at Stn CS3b. (a) Eq. (3) is fitted to the data where the intercept of the curve on the $y$-axis has been subtracted for the ${ }^{13} \mathrm{C}$ and ${ }^{14} \mathrm{C}$ curves, but not for ${ }^{15} \mathrm{NO}_{3}{ }^{-}$(see 'Materials and methods'). The carbon and nitrate axes differ by the Redfield $\mathrm{C}: \mathrm{N}$ ratio of 6.625 , such that the uptake conforms to Redfield stoichiometry where the curves intersect. (b) Ratio of ${ }^{14} \mathrm{C}$ and ${ }^{13} \mathrm{C}$ photosynthesis to ${ }^{15} \mathrm{NO}_{3}{ }^{-}$uptake with irradiance via comparison of the fitted curves in (a). Data have been spectrally corrected so that irradiance corresponds to that in situ and the vertical grey dashed lines represent the maximum in situ irradiance for 


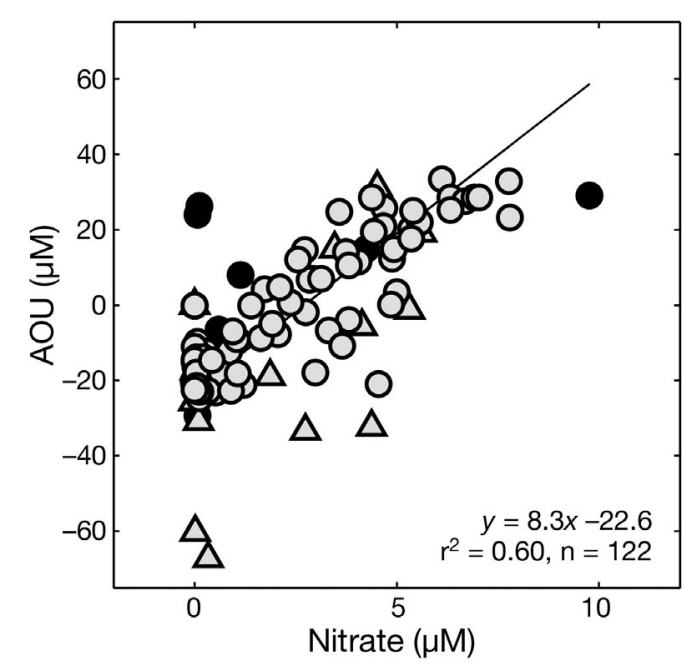

Fig. 10. Dissolved oxygen (as apparent oxygen utilisation, AOU) against nitrate concentration for all available stations. Statistics shown are the result of a linear model II regression $(p \ll 0.001)$, although close inspection suggests that a nonlinear regression could also be applied. Outliers to the correlation occurred at U2 (triangles) and P1 (solid circles), which exhibited particularly narrow (U2) and broad (P1) thermoclines (see 'Results' for explanation of outlying values). The outliers are included in the regression statistics

face maximum (Fig. 2) located towards the base of the thermocline and on the nitracline (Figs. $2 \& 3$ ), reflecting the characteristic structure of seasonally stratified waters on the NW European shelf with a nutrient-depleted SML (Pingree et al. 1978, Richardson et al. 2000). When considered in terms of density, the vertical distributions of chl $a$ and nitrate showed a similar pattern between locations and over time (Fig. 3). Levels of chl $a$ in the SML away from frontal regions and coastal waters were in the range 0.2 to $0.5 \mathrm{mg} \mathrm{m}^{-3}$ and consistent with both previous observations (Pingree et al. 1976) and satellite estimates (Joint \& Groom 2000). Higher values occur locally (for example, to the northwest of station P1, see Fig. 1b) with occasional summer blooms, probably attributable to the widespread dinoflagellate Karenia mikimotoi (Holligan et al. 1984a), seen on satellite images (e.g. Fig. 3d,e in Joint \& Groom 2000).

Maximum observed concentrations of chl $a$ in the thermocline were in the range of 1 to $2 \mathrm{mg} \mathrm{m}^{-3}$ (Fig. 2a,b), with values $>2 \mathrm{mg} \mathrm{m}^{-3}$ at some stations close to tidal fronts. How typical these values are for the Celtic Sea is difficult to assess, as few measurements have been made previously and satellite sensors cannot detect the SCM. Estimates of watercolumn-integrated chl a from the Seasoar section (Fig. 2c) indicate that higher values $\left(>60 \mathrm{mg} \mathrm{m}^{-2}\right)$ correspond to regions where concentrations at the SCM were also relatively high $\left(\geq 1.5 \mathrm{mg} \mathrm{m}^{-3}\right)$. There are several possible causes of variations in chl a concentrations within the thermocline, including: (1) differences in the degree of acclimation of the phytoplankton to low light (reflecting, in turn, the effects of clouds and water transparency on irradiance at the level of the SCM; Table 2), (2) differences in phytoplankton taxonomy (Hickman et al. 2009), (3) differences in nutrient supply from, or loss of phytoplankton standing stock to, the BML due to changes in mixing over seabed topography or with spring-neap tides (Sharples et al. 2001b, Rippeth et al. 2005, Tweddle 2007), and (4) the effects of trophic interactions such as changes in grazing pressure or nutrient recycling (Taylor et al. 1986).

Comparison of the chl a data from the 2003 and 2005 PP stations (Table 1), to the distribution of chl a along the 2003 Seasoar section between the shelf edge and the tidal front (Fig. $2 \mathrm{a}-\mathrm{c}$ ) indicates that these stations are representative of the stratified region of the Celtic Sea in mid-summer.

\section{Observed rates of primary production}

Estimated rates of PP for the seasonally stratified region of the Celtic Sea were 174 to $386 \mathrm{mg} \mathrm{C} \mathrm{m}^{-2}$ $\mathrm{d}^{-1}$, the range representing estimates for cloudy and sunny conditions (Table 2 ). These estimated rates are comparable with independent measurements performed on the 2003 cruise (Maranon et al. 2005) and, when variations in surface irradiance are taken into account, with earlier field observations in midsummer (Joint \& Pomroy 1983, Holligan et al. 1984b, Joint et al. 1986). Around half of the total watercolumn production occurred within the thermocline (Table 2, Fig. 8) with the thermocline contribution to total production increasing by $10 \%$ under sunny compared to cloudy conditions (Fig. 8). The assumed 4 -fold contrast in daily incident irradiance between the cloudy and sunny conditions resulted in a 2-fold change in integrated production within the SML and a 3-fold change within the thermocline.

During summer, the vertical gradient in nutrient availability is a key determinant of the distribution of phytoplankton and subsequently PP (Pingree et al. 1978, Holligan et al. 1984b). However, within this stratified regime, the most important factor governing observed day-to-day variability in PP was incident irradiance, particularly within the thermocline. The sensitivity of photosynthetic rates in the thermocline to irradiance results from acclimation of the phytoplankton to low light (MacIntyre et al. 2002, 
Moore et al. 2006) not being sufficient to achieve $P_{\mathrm{m}}^{*}$ under in situ conditions (Fig. 5). Increased cellular chl $a$ with depth was accompanied by expected changes in photosynthetic parameters (Fig. 4), so that photosynthetic rates within the thermocline were light-limited (Fig. 5) and showed a wider range between cloudy and sunny days than those within the SML. Differences in PP between stations were less than the differences between cloudy and sunny conditions for each station (Table 2, Fig. 7b). Thus, for the seasonally stratified Celtic Sea as a whole, dayto-day variability in sea surface irradiance is likely to affect PP at least as much as the observed variability in phytoplankton biomass (or physiology), which may result from, for example, spring-neap variability in nutrient supply (Sharples et al. 2001b, Rippeth et al. 2005).

The correlation between integrated PP and chl a was significant only when the SML and thermocline were considered separately, as might be expected from known differences between these 2 layers with respect to taxonomy (Hickman et al. 2009) and photophysiological properties (Fig. 4). Layer-integrated rates of PP were more strongly dependent on $P^{*}$ for surface water and $\alpha_{\text {insitu }}$ for the thermocline. However, the observed variability in these 2 physiological parameters for depths at which they are important determinants of rates of production (Fig. 4) could not be correlated with particular environmental properties.

Based on the data presented in Table 2, the spatially-averaged water column PP during a summer stratified period of $120 \mathrm{~d}$ in the Celtic Sea is estimated to be 21 to $46 \mathrm{~g} \mathrm{C} \mathrm{m}^{-2} \mathrm{yr}^{-1}$ (assuming constant photophysiology), with the range representing the difference between persistently cloudy or sunny weather conditions. Correspondingly, estimated PP within the seasonal thermocline is 8 to $23 \mathrm{~g} \mathrm{C} \mathrm{m}^{-2}$ $\mathrm{yr}^{-1}$, depending on irradiance. The total PP values are comparable to previous estimates for the summer months $\left(\sim 50 \mathrm{~g} \mathrm{C} \mathrm{m}^{-2}\right)$ based on monthly observations at a single mid-shelf station (Joint et al. 1986) or on satellite measurements (Joint \& Groom 2000) both of which are likely to be biased towards conditions of high surface irradiance. Inspection of the productivity profiles (Fig. 6) indicates that about half of the thermocline production can be attributed to the nitracline (lower thermocline).

\section{Estimation of new production}

The typical distribution of water properties across the seasonal thermocline in the Celtic Sea is illustrated schematically in Fig. 11. The SCM is situated in the lower thermocline on the upper nitracline, whilst, by contrast, the oxygen maximum is in the upper thermocline and at a depth where the nitrate concentration has reached its minimum value. This pattern is consistent with previous observations for summer stratified waters in the western English Channel and Celtic Sea (Holligan et al. 1984a,b) and in the North Sea (Richardson \& Bo Pedersen 1998, Richardson et al. 2000). The data from the Celtic Sea demonstrate a correspondence between increasing nitrate and decreasing oxygen with depth across the chl a maximum (see Fig. 10). The presence of an oxygen saturation maximum indicates net production of oxygen within the thermocline with the potential for loss both to the BML (where oxygen is consumed by heterotrophs in water and sediments) and to the SML (where the oxygen level reflects the balance between biological processes and exchange with the atmosphere). Thus the distributions of both nitrate and oxygen provide information about rates of new production within the seasonal thermocline.

Previous estimates for new production in seasonally stratified waters on the NW European shelf have been based on indirect measures of vertical mixing derived from mean vertical fluxes of heat and salt

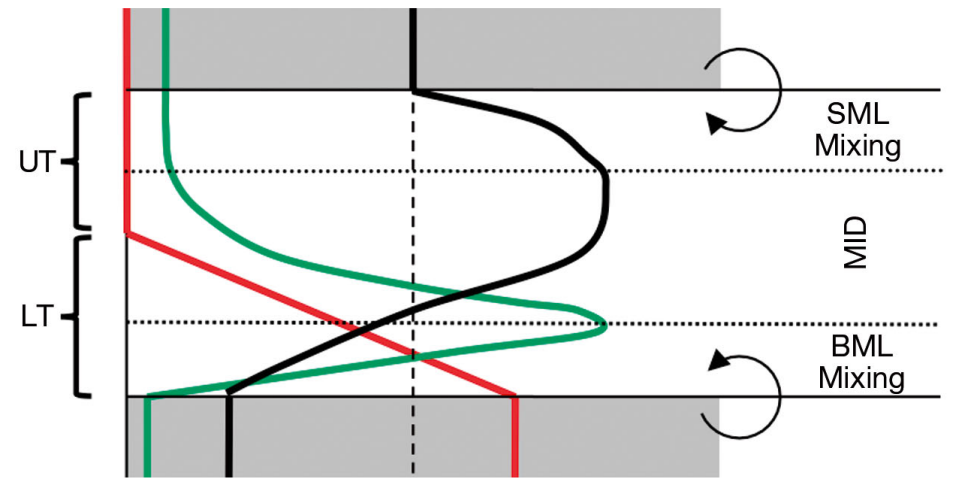

Fig. 11. Schematic view of chlorophyll a (chl $a$, green line), nitrate concentrations (red line) and dissolved oxygen saturation (thick black line) through the thermocline. Horizontal solid lines and shaded region define the upper and lower boundaries of the thermocline. The horizontal dotted lines indicate the limit of mixing across the thermocline boundaries, defining a 'surface mixed layer (SML) mixing' and 'bottom mixed layer (BML) mixing' region bounding a relatively stable 'mid'-region that is less affected by mixing processes. The vertical dashed line indicates the saturation level of dissolved oxygen in the SML. UT and LT refer to the upper and lower thermocline regions in Table 3, as defined by the location of the nitracline 
(Pingree \& Pennycuick 1975, Holligan et al. 1984b), turbulence measurements (Sharples et al. 2001b), oxygen budgets (Richardson et al. 2000) and estimates of the f-ratio from measurements of ${ }^{15} \mathrm{NO}_{3}{ }^{-}$and ${ }^{15} \mathrm{NH}_{4}{ }^{+}$uptake (Weston et al. 2005) for the thermocline. Here we consider an oxygen budget and estimates of nitrate uptake in the context of turbulence measurements (e.g. Rippeth et al. 2005) undertaken during the 2003 and 2005 cruises (Table 3).

Measurements of the nitrate gradient and of diapycnal mixing at the base of the thermocline give an upward flux of nitrate from the BML of $2 \mathrm{mmol} \mathrm{N} \mathrm{m}^{-2}$ $\mathrm{d}^{-1}$ at Stn U2 (Sharples et al. 2001b), and this value is considered to be a reasonable estimate for the wider Celtic Sea region (Tweddle 2007). The vertical nitrate profile indicates that this flux of 'new' nitrate from the BML is fully utilised within the thermocline (Table 3). Since it depends on the vertical eddy diffusivity, the precise magnitude of the nitrate flux will vary with time, for example, in response to changes in tidal mixing, wind mixing or internal wave activity (Rippeth et al. 2005, Tweddle 2007, Palmer et al. 2008).

An oxygen 'surplus' in the thermocline was calculated by integrating oxygen saturation in excess of a linear gradient between saturation levels in the BML and SML. The oxygen surplus was, on average, 0.58 $\pm 1 \mathrm{~mol} \mathrm{O}_{2} \mathrm{~m}^{-2}(\mathrm{n}=79)$. Assuming the dominance of vertical mixing in these systems (Simpson \& Hunter 1974, Palmer et al. 2008), a characteristic timescale for thermocline ventilation $(t)$ can be estimated as $t=$ $L^{2} / 2 K_{z}$ (Denman \& Gargett 1983), where $L(\mathrm{~m})$ is the mixing length scale and $K_{z}\left(\mathrm{~m}^{2} \mathrm{~s}^{-1}\right)$ is the vertical eddy diffusivity. Taking a typical value for thermocline thickness, $L=25 \mathrm{~m}$ (Table 1), and vertical eddy diffusivity at the nitracline, $K_{z}=5 \times 10^{-5} \mathrm{~m}^{2} \mathrm{~s}^{-1}$ (Sharples et al. 2001b, Hickman et al. 2009) then the ventilation timescale is of the order of $70 \mathrm{~d}$. Assuming steady state and Redfield stoichiometry, the oxygen surplus would thus be equivalent to a new production rate of $1 \mathrm{mmol} \mathrm{N} \mathrm{m}^{-2} \mathrm{~d}^{-1}$ (Table 3). Given the assumptions in the calculation of the ventilation timescale (Denman \& Gargett 1983), this value for new production is considered to be an order of magnitude estimate.

Direct ${ }^{15} \mathrm{NO}_{3}{ }^{-}$uptake rates (Fig. 9) ranged from 77 to $130 \mu \mathrm{mol} \mathrm{N} \mathrm{m}^{-3} \mathrm{~d}^{-1}$ for the SCM and 11 to $28 \mu \mathrm{mol} \mathrm{N}$ $\mathrm{m}^{-3} \mathrm{~d}^{-1}$ in the upper thermocline, with the lower values in the range corresponding to cloudy conditions. Observed rates of ${ }^{15} \mathrm{NO}_{3}{ }^{-}$uptake were equivalent to 0.9 to $1.2 \mathrm{mmol} \mathrm{N} \mathrm{m}^{-2} \mathrm{~d}^{-1}$ for the lower thermocline (nitracline) and a value $10 \%$ of this magnitude for the upper thermocline, calculated from the measured ${ }^{15} \mathrm{NO}_{3}{ }^{-}$uptake versus irradiance responses scaled by chl $a$ and PAR through the thermocline (Table 3).

Given the different approaches and

Table 3. Summary of thermocline nitrate, oxygen and photosynthetic carbon fluxes (for details see 'Results'). Conversion of oxygen and carbon fluxes to units of nitrogen is based on Redfield stoichiometry. Where applicable, ranges indicate estimates for cloudy and sunny conditions. Rates of ${ }^{14} \mathrm{C}$ fixation are derived from Table 2, where that in the lower thermocline (LT), defined as the region where nitrate concentrations were above the limit of detection ( $>0.1 \mu \mathrm{M}$, i.e. the nitracline), accounts for 49 and $53 \%$ of thermocline primary production for cloudy and sunny conditions, respectively, and the remainder is attributed to the upper thermocline (UT). Rates of ${ }^{15} \mathrm{NO}_{3}{ }^{-}$uptake integrated through the LT and UT are based on the light response of ${ }^{15} \mathrm{NO}_{3}{ }^{-}$uptake measured in the UT and SCM, respectively, and account for gradients in chlorophyll $a(\mathrm{chl} a)$ and photosynthetically available radiation (PAR). A value for nitrogen flux derived from ${ }^{14} \mathrm{C}$ fixation that exceeds that from ${ }^{15} \mathrm{NO}_{3}{ }^{-}$uptake experiments implies utilisation of regenerated forms of nitrogen. Conversely, values for nitrogen flux derived from ${ }^{14} \mathrm{C}$ fixation that are lower than values from ${ }^{15} \mathrm{NO}_{3}{ }^{-}$uptake imply an excess of nitrogen relative to carbon fixation, such as occurs for the nitracline during cloudy conditions

\begin{tabular}{|c|c|c|c|}
\hline Flux & & $\begin{array}{c}\text { Flux } \\
\text { value }\end{array}$ & $\begin{array}{c}\text { Equivalent } \\
\mathrm{N} \text { flux }(\mathrm{mmol} \mathrm{N} \\
\left.\mathrm{m}^{-2} \mathrm{~d}^{-1}\right)\end{array}$ \\
\hline $\mathrm{NO}_{3}$ flux into thermocline & & $2 \mathrm{mmol} \mathrm{N} \mathrm{m}{ }^{-2} \mathrm{~d}^{-1}$ & 2 \\
\hline Net $\mathrm{O}_{2}$ production & & $8.6 \mathrm{mmol} \mathrm{O}_{2} \mathrm{~m}^{-2} \mathrm{~d}^{-1}$ & 1 \\
\hline${ }^{15} \mathrm{NO}_{3}^{-}$uptake & $\begin{array}{l}\text { UT } \\
\text { LT }\end{array}$ & $\begin{array}{r}0.10-0.12 \mathrm{mmol} \mathrm{N} \mathrm{m} \mathrm{m}^{-2} \mathrm{~d}^{-1} \\
0.9-1.2 \mathrm{mmol} \mathrm{N} \mathrm{m}^{-2} \mathrm{~d}^{-1}\end{array}$ & $\begin{array}{c}0.10-0.12 \\
0.9-1.2\end{array}$ \\
\hline${ }^{14} \mathrm{C}$ fixation & $\begin{array}{l}\text { UT } \\
\text { LT }\end{array}$ & $\begin{array}{l}34-89 \mathrm{mg} \mathrm{C} \mathrm{m}^{-2} \mathrm{~d}^{-1} \\
33-100 \mathrm{mg} \mathrm{C} \mathrm{m}^{-2} \mathrm{~d}^{-1}\end{array}$ & $\begin{array}{l}0.4-1.1 \\
0.4-1.3\end{array}$ \\
\hline
\end{tabular}
methodological caveats, the 3 independent indicators of the amount of production fuelled by nitrate from the BML for the Celtic Sea during summer lie within the range of estimates for total production for the thermocline as a whole (Tables $2 \& 3$ ). To first order, it thus appears that all the estimated PP within the thermocline could be fuelled by 'new' nitrate from the BML. However, around half of the PP occurred in the upper thermocline where nitrate was depleted (Figs. 3 \& 6 ) and production fuelled by regenerated (reduced) nitrogen species is likely to be significant (Le Corre et al. 1993, Weston et al. 2005). Thus, it appears that an 'excess' of nitrate is being assimilated on the nitracline relative to rates of photosynthetic carbon fixation (particularly under low light) and to $\mathrm{C}: \mathrm{N}$ ratios for particulate organic matter within this layer, even if there is no recycling of nitrogen. A similar excess in nitrate uptake can 
be inferred from the earlier results of Holligan et al. (1984b) for Stn E5 in the southern Celtic Sea; the estimated flux of nitrate into the seasonal thermocline (up to $2.2 \mathrm{mmol} \mathrm{N} \mathrm{m} \mathrm{N}^{-2} \mathrm{~d}^{-1}$ ) was equivalent to new production accounting for more than half the total water column production $\left(\sim 30 \mathrm{mmol} \mathrm{C} \mathrm{m}{ }^{-2} \mathrm{~d}^{-1}\right.$ under average surface irradiance), which again is a high proportion for a well stratified water column.

Three main conclusions can be drawn from the results summarised in Table 3.

(1) Given the inherent uncertainties in the observational and experimental procedures, estimates of ${ }^{15} \mathrm{NO}_{3}{ }^{-}$uptake, turbulent nitrate fluxes at the nitracline and net oxygen production give broadly consistent results. It would thus be difficult to justify attaching significance to any remaining differences between these estimates.

(2) In the upper thermocline, the measured rates of ${ }^{15} \mathrm{NO}_{3}{ }^{-}$uptake account for about $30 \%$ of the nitrogen requirement of phytoplankton as indicated by ${ }^{14} \mathrm{C}$ fixation (i.e. f-ratio $=0.3$ ), a value that is consistent with other observations for surface, nitrate-depleted waters of shelf seas (Harrison 1990, Bjørnsen et al. 1993, Weston et al. 2005).

(3) By contrast, in the $\mathrm{SCM}_{1}{ }^{15} \mathrm{NO}_{3}{ }^{-}$uptake is equal to or potentially exceeds the nitrogen requirement of phytoplankton carbon fixation even if it is assumed that no regenerated forms of nitrogen are being assimilated, which is highly unlikely (Le Corre et al. 1993, Weston et al. 2005). Much of the 'excess' ${ }^{15} \mathrm{NO}_{3}{ }^{-}$ taken up can be accounted for by dark uptake (Fig. 9), as observed by Weston et al. (2005).

Confidence in our ${ }^{15} \mathrm{NO}_{3}{ }^{-}$uptake data for the SCM is provided by the parallel ${ }^{13} \mathrm{C}$ and ${ }^{14} \mathrm{C}$ fixation rates (Fig. 9), and by similarity to previous observations of 'excess' nitrate removal within the SCM of both shelf sea (Bjørnsen et al. 1993) and oceanic environments (Painter et al. 2007). In addition, as mentioned above, the estimated ${ }^{15} \mathrm{NO}_{3}{ }^{-}$uptake at the nitracline is equal to or less than the nitrate flux estimated from turbulence measurements (Sharples et al. 2001b).

We acknowledge the potential for significant error in estimates of biological rates within discrete layers associated with strong gradients in environmental parameters such as light and nitrate. For example, the C:N uptake ratio for SCM phytoplankton is dependent on light intensity (Fig. 9) and a doubling of the estimated mean light level would bring the ${ }^{14} \mathrm{C}^{15} \mathrm{NO}_{3}{ }^{-}$uptake ratio for the Celtic Sea SCM close to the Redfield ratio, again assuming that no regenerated forms of nitrogen are being utilised. A discrepancy of this magnitude appears unlikely, although vertical movement of the thermocline (Fig. 2d,e) can potentially account for some changes in irradiance for phytoplankton in the SCM. Similarly, data presented by Painter et al. (2007) over a broad layer between the 1.0 and $0.1 \%$ irradiance levels along a meridional section across the Atlantic Ocean suggest that anomalously low C:N uptake ratios cannot be explained by a systematic error in light measurements. Other possible sources of error, including differences in the timescales for turnover of carbon and nitrogen, extrapolation of short-term (hours) measured rates of uptake to daily rates and underestimation of carbon fixation when chl a levels are low, were also discussed by Le Bouteiller (1993).

Despite such uncertainties, the presented data still suggest that more nitrate is being removed within the nitracline than can be accounted for by photosynthetically-fixed carbon. Moreover, this discrepancy is greatest under low light (cloudy conditions). The apparent excess in nitrate utilisation is unlikely to be fully explained by conversion of nitrate to dissolved organic nitrogen (DON) (Bronk \& Ward 2005), as has been suggested for the nitracline in oceanic waters (Painter et al. 2007), as some parallel dissolved organic carbon (DOC) release must also occur. Indeed, within the studied system, DOC excretion is around $20 \%$ of PP (Maranon et al. 2005).

One likely explanation for the relatively high uptake rates of nitrate in the Celtic Sea thermocline is utilisation by heterotrophic bacteria (Allen et al. 2001, 2002, Zubkov et al. 2001, Wawrik et al. 2012). Heterotrophic bacteria are likely to have a higher requirement for dissolved inorganic nitrogen when utilising carbon-rich (relative to their composition) particulate or dissolved organic matter (Kirchman 2000), with the nutrient-poor summer surface layer and upper thermocline a highly likely source of such material, as indicated by the observed higher POC:PON observed in the SML compared to SCM. A summer nitracline receiving sinking particulate matter, or a diffusive flux of dissolved organic matter, from these overlying waters is thus likely to provide a favourable environment for such organisms. Any nitrate derived nitrogen assimilated by bacteria would likely be readily incorporated into the rest of the planktonic food chain via ingestion by heterotrophs or mixotrophic eukaryotic phytoplankton (Raven 1997, Mitra \& Flynn 2010, Ward et al. 2011, Hartmann et al. 2012). Considerable evidence now exists for the quantitative importance of mixotrophy within marine nutrient- and light-limited environments (see Mitra \& Flynn 2010, Ward et al. 2011), but how this process affects rates of PP (by acting as an alternative source of nutrients through bactivory) 
or relates to the estimation of new production (by providing an alternative route for nitrate assimilation) is not well understood. Furthermore, direct nitrate assimilation by SCM phytoplankton increases with irradiance (Fig. 10) so that, under sunny conditions, mixotrophy is likely to become less important in meeting the nitrogen requirements of photosynthetic organisms.

The dynamics of carbon fixation and nutrient uptake (as well as nutrient regeneration) within thermoclines characterized by strong gradients in both light and nutrients and by varying irradiance due to clouds (Banse 1987) are bound to be complex. At the community level, it is perhaps unsurprising that uptake of excess nitrate under low light might be balanced by excess carbon under high light (Fig. 9), and/or by excretion of nitrogenous compounds. Within the layered system represented by the highlight, low-nitrate upper and low-light, high-nitrate lower thermocline (Fig. 11), downward transfer of high $\mathrm{C}: \mathrm{N}$ organic material or upward transfer of low $\mathrm{C}: \mathrm{N}$ material can be speculated to contribute to this balance.

\section{Wider ecological implications}

The main focus of this paper was to determine the importance of the seasonal thermocline for PP and to estimate the proportion of PP in summer that can be considered to be fuelled by 'new' nitrogen. In the Celtic Sea, around half of the summer PP occurs within the thermocline (Table 2, Fig. 8), and of this fraction, about half can be attributed to the lower thermocline (Fig. 6, Table 3), where nitrate is available for phytoplankton growth. Thus new production potentially contributes up to $25 \%$ of water column PP. Representative values of 80 to $160 \mathrm{mg}$ C $\mathrm{m}^{-2} \mathrm{~d}^{-1}$ for new production (Table 3 ) are equivalent to a total of $\sim 10$ to $19 \mathrm{~g} \mathrm{C} \mathrm{m}^{-2}$ for a summer period of $120 \mathrm{~d}$. The equivalent new production in the spring bloom, assuming that the initial nitrate concentration is $8 \mu \mathrm{M}$, that the average depth of the nitratedepleted surface layer is $25 \mathrm{~m}$ and that the $\mathrm{C}: \mathrm{N}$ for phytoplankton is 6.625 (Redfield ratio), is $18.5 \mathrm{~g} \mathrm{C}$ $\mathrm{m}^{-2}$. On this basis, summer new production in the Celtic Sea is of a similar magnitude to (and most likely around half) that associated with the spring bloom.

By comparison, a thermocline oxygen budget based on replenishment over a spring-neap tidal cycle within a frontal region just north of the Dogger Bank in the North Sea (Richardson et al. 2000) resulted in a value for summer new production of 160 to $320 \mathrm{mg} \mathrm{C}$ $\mathrm{m}^{-2} \mathrm{~d}^{-1}$, again comparable to the spring bloom. A later study in the same area by Weston et al. (2005) reported that on average $58 \%$ (equivalent to $424 \mathrm{mg}$ $\left.\mathrm{C} \mathrm{m}{ }^{-2} \mathrm{~d}^{-1}\right)$ of the water column PP $\left({ }^{14} \mathrm{C}\right)$ occurred within the chl a maximum layer, with the f-ratio (derived from ${ }^{15} \mathrm{NO}_{3}{ }^{-} /{ }^{15} \mathrm{NO}_{3}{ }^{-}+{ }^{15} \mathrm{NH}_{4}{ }^{+}$from ${ }^{15} \mathrm{~N}$ uptake experiments) varying between 0.11 and 0.48 . These relatively low f-ratios suggest that regenerated sources of nitrogen were relatively important compared to nitrate. Physical conditions and associated assumptions need to be considered when comparing these Celtic and North Sea estimates. In particular, for the frontal region of the North Sea, nutrient fluxes and thermocline ventilation were attributed to tidal pumping of bottom water during frontal migration over the neap-spring tidal cycle.

Variations in environmental forcing will modify the balance of processes within the thermocline, causing changes to the precise locations of primary and new production (Taylor et al. 1986), and the chl $a$, nitrate and dissolved oxygen profiles (Figs. $6 \&$ 11). The feedbacks between biological (e.g. acclimation, growth, predation) and physical (e.g. mixing, nitrate flux) processes within the thermocline are complicated and act on different timescales. For example, enhanced nitrate supplied during periods of increased turbulent mixing around spring tides (Sharples et al. 2001b, Rippeth et al. 2005) may not be immediately assimilated by phytoplankton, particularly if coincident with cloudy weather (Banse 1987) and/or stripping of standing stock of phytoplankton and other microbes to the BML (Sharples et al. 2001b, 2007). This situation could increase chl $a$ and nitrate concentrations higher up in the density gradient, such as observed at Stns B2a and CS3a (Fig. 3). The amount of nitrate uptake relative to carbon fixation may thus, for example, be greatest during cloudy spells that follow spring tides compared to sunny periods following neaps. However, despite the range of tidal and irradiance conditions experienced during this study, processes within the thermocline were always sufficient to fully utilise the nitrate supplied from the BML so that none could be observed reaching the SML (Banse 1987). Further, the slope of the regression between nitrate and AOU of 8.3 (Fig. 10) indicates that, on average, these elements were cycled in close to Redfield proportions.

In contrast to the direct sensitivity of summertime carbon fixation to surface irradiance, the irradiance control on new production is less clear. The magnitude of new production is determined by the nitrate flux from the BML, which in turn depends on the ver- 
tical eddy diffusivity and, thus, physical mixing conditions. In addition, the nitrate flux also depends on the nitrate gradient (Sharples et al. 2001b) and may subsequently be affected by irradiance as a result of light-driven changes in photosynthetic rates (and nitrate uptake) at the nitracline. However, the effect of changes in the nitrate gradient on the flux is likely to be small compared to variations in mixing.

\section{CONCLUSIONS}

We have shown that the average PP for the seasonally stratified Celtic Sea was 170 to $390 \mathrm{mg} \mathrm{C} \mathrm{m}^{-2} \mathrm{~d}^{-1}$, of which 40 to $50 \%$ occurred within the thermocline. Of the equivalent seasonal production, 10 to $19 \mathrm{~g} \mathrm{C}$ $\mathrm{m}^{-2}$ was fuelled by new nitrate from the BML, which represents $25 \%$ of summer PP and is around half that expected for the spring bloom. The main control on day-to-day variability in the magnitude of summer PP was incident surface irradiance. Although variability in nutrient fluxes from the BML into the seasonal thermocline is likely to influence PP, the form of this response is far from clear. Not only do physical processes (e.g. mixing by tides, internal waves, wind) and biological processes (phytoplankton growth and loss) interact over various scales within a stratified system, but important biological feedbacks on the distributions of environmental properties such as vertical gradients in nutrients and light remain poorly parameterized. Reliable prediction of ecosystem responses to external forcing will depend on new measurements and numerical models (e.g. Taylor et al. 1986, Allen et al. 2004) taking careful account of thermocline structure as illustrated in Fig. 11 and addressing key biological processes, such as the potential effects of vertically migrating organisms, heterotrophic nitrate uptake, mixotrophy and grazing within the SCM, on the transformation and redistribution of nutrients in the water column.

Acknowledgements. We thank Y.N. Kim and M. Qurban for nutrient data collection and D. Purdie for oxygen measurements at sea, as well as S. Painter, A. Poulton and R. Head for their help with analyses in the laboratory. We also thank the officers and crew of the RRS 'James Clark Ross' (JR98) and RRS 'Charles Darwin' (CD173) for their support at sea. Satellite images were provided by the NERC Earth Observation Data Acquisition and Analysis Service (NEODAAS) at Plymouth Marine Laboratory (UK). Thanks also to the anonymous reviewers whose comments improved on an earlier version of this manuscript. This work was supported by the Natural Environment Research Council (NERC) UK, through grant numbers NER/A/S/2001/00449, NE/H015930/2 and a NERC studentship to A.E.H.

\section{LITERATURE CITED}

Allen AE, Booth MG, Frischer ME, Verity PG, Zehr JP, Zani S (2001) Diversity and detection of nitrate assimilation genes in marine bacteria. Appl Environ Microbiol 67:5343-5348

Allen AE, Howard-Jones MH, Booth MG, Frischer ME, Verity PG, Bronk DA, Sanderson MP (2002) Importance of heterotrophic bacterial assimilation of ammonium and nitrate in the Barents Sea during summer. J Mar Syst 38:93-108

> Allen JI, Siddorn JR, Blackford JC, Gilbert FJ (2004) Turbulence as a control on the microbial loop in a temperate seasonally stratified marine systems model. J Sea Res 52:1-20

- Banse K (1987) Clouds, deep chlorophyll maxima and the nutrient supply to the mixed layer of stratified water bodies. J Plankton Res 9:1031-1036

Bjørnsen PK, Kaas H, Kaas H, Nielsen TG, Olsen M, Richardson K (1993) Dynamics of a subsurface phytoplankton maximum in the Skagerrak. Mar Ecol Prog Ser 95:279-294

> Bouman HA, Platt T, Sathyendranath S, Irwin BD, Wernand MR, Kraay GW (2000) Bio-optical properties of the subtropical North Atlantic. II. Relevance to models of primary production. Mar Ecol Prog Ser 200:19-34

Brewer PG, Riley JP (1965) The automatic determination of nitrate in sea water. Deep-Sea Res I 12:765-772

Bricaud A, Stramski D (1990) Spectral absorption coefficients of living phytoplankton and nonalgal biogenous matter: a comparison between the Peru upwelling area and the Sargasso Sea. Limnol Oceanogr 35:562-582

Bronk DA, Ward BB (2005) Inorganic and organic nitrogen cycling in the Southern California Bight. Deep-Sea Res I 52:2285-2300

Cochlan WP, Harrison PJ, Denman KL (1991) Diel periodicity of nitrogen uptake by marine phytoplankton in nitrate-rich environments. Limnol Oceanogr 36: 1689-1700

> Denman KL, Gargett AE (1983) Time and space scales of vertical mixing and advection of phytoplankton in the upper ocean. Limnol Oceanogr 28:801-815

> Dickey-Collas M, Gowen RJ, Fox CJ (1996) Distribution of larval and juvenile fish in the Western Irish Sea: relationship to phytoplankton, zooplankton biomass and recurrent physical features. Mar Freshw Res 47:169-181

> Dugdale RC, Goering JJ (1967) Uptake of new and regenerated forms of nitrogen in primary productivity. Limnol Oceanogr 12:196-206

- Fasham MJR, Holligan PM, Pugh PR (1983) The spatial and temporal development of the spring phytoplankton bloom in the Celtic Sea, April 1979. Prog Oceanogr 12:87-145

Glibert PM, Capone DG (1993) Mineralization and assimilation in aquatic, sediment and wetland systems. In: Knowles R, Blackburn TH (eds) Nitrogen isotope techniques. Academic Press, San Diego, CA, p 243-272

Halsey KH, Milligan AJ, Behrenfeld MJ (2010) Physiological optimization underlies growth rate-independent chlorophyll-specific gross and net primary production. Photosynth Res 103:125-137

> Harrison WG (1990) Nitrogen utilization in chlorophyll and primary productivity maximum layers: an analysis based on the f-ratio. Mar Ecol Prog Ser 60:85-90 
Hartmann M, Grob C, Tarran GA, Martin AP, Burkill PH, Scanlan DJ, Zubkov MV (2012) Mixotrophic basis of Atlantic oligotrophic ecosystems. Proc Natl Acad Sci USA 109:5756-5760

> Heath MR, Beare DJ (2008) New primary production in northwest European shelf seas, 1960-2003. Mar Ecol Prog Ser 363:183-203

- Hickman AE, Holligan PM, Moore CM, Sharples J, Krivtsov V, Palmer MR (2009) Distribution and chromatic adaptation of phytoplankton within a shelf sea thermocline. Limnol Oceanogr 54:525-536

> Holligan PM, Harris RP, Newell RC, Harbour DS and others (1984a) Vertical distribution and partitioning of organic carbon in mixed, frontal and stratified waters of the English Channel. Mar Ecol Prog Ser 14:111-127

Holligan PM, Williams PJ, Purdie D, Harris RP (1984b) Photosynthesis, respiration and nitrogen supply of plankton populations in stratified, frontal and tidally mixed shelf waters. Mar Ecol Prog Ser 17:201-213

> Jassby AD, Platt T (1976) Mathematical formulation of the relationship between photosynthesis and light for phytoplankton. Limnol Oceanogr 21:540-547

> Joint IR, Groom SB (2000) Estimation of phytoplankton production from space: current status and future potential of satellite remote sensing. J Exp Mar Biol Ecol 250:233-255

Joint IR, Pomroy AJ (1983) Production of picoplankton and small nanoplankton in the Celtic Sea. Mar Biol 77:19-27

$>$ Joint IR, Owens NJP, Pomroy AJ (1986) Seasonal production of photosynthetic picoplankton and nanoplankton in the Celtic Sea. Mar Ecol Prog Ser 28:251-258

Kirchman DL (2000) Uptake and regeneration of inorganic nutrients by marine heterotrophic bacteria. In: Kirchman DL (ed) Microbial ecology of the oceans. John Wiley, Hoboken NJ, p 261-288

Kirk JTO (1994) Light and photosynthesis in aquatic ecosystems. Cambridge University Press, Cambridge

Lavin A, Valdes L, Sanchez F, Abaunza P and others (2006) The Bay of Biscay: the encountering of the ocean and shelf. In: Robinson AR, Brink K (eds) The sea. Vol 14B: the global coastal ocean: interdisciplinary regional studies and synthesis. Harvard University Press, Cambridge, MA, p 1003-1031

Le Bouteiller A (1993) Comparison of in-bottle measurements using ${ }^{15} \mathrm{~N}$ and ${ }^{14} \mathrm{C}$. ICES J Mar Sci 197:121-131

> Le Corre P, L'Helguen S, Wafar M (1993) Nitrogen source for uptake by Gyrodinium cf. aureolum in a tidal front. Limnol Oceanogr 38:446-451

> MacIntyre HL, Kana TM, Anning T, Geider RJ (2002) Photoacclimation of photosynthesis irradiance response curves and photosynthetic pigments in microalgae and cyanobacteria. J Phycol 38:17-38

Maranon E, Cermeno P, Perez V (2005) Continuity in the photosynthetic production of dissolved organic carbon from eutrophic to oligotrophic waters. Mar Ecol Prog Ser 299:7-17

> Mitra A, Flynn KJ (2010) Modelling mixotrophy in harmful algal blooms: more or less the sum of the parts? J Mar Syst 83:158-169

- Moore CM, Suggett DJ, Hickman AE, Kim YN and others (2006) Phytoplankton photoacclimation and photoadaptation in response to environmental gradients in a shelf sea. Limnol Oceanogr 51:936-949

Morel A, Antoine D, Babin M, Dandonneau Y (1996) Measured and modeled primary production in the northeast Atlantic (EUMELI JGOFS program): the impact of nat- ural variations in photosynthetic parameters on model predictive skill. Deep-Sea Res I 43:1273-1304

- Muller-Karger FE, Varela R, Thunell R, Luerssen R, Hu C, Walsh JJ (2005) The importance of continental margins in the global carbon cycle. Geophys Res Lett 32:L01602 doi:10.1029/2004GL021346

Painter SC, Sanders R, Poulton AJ, Woodward EMS, Lucas MI, Chamberlain K (2007) Nitrate uptake at photic zone depths is not important for export in the subtropical ocean. Global Biogeochem Cycles 21:GB4005 doi:1029/ 2006GB002807

Palmer MR, Rippeth TP, Simpson JH (2008) An investigation of internal mixing in a seasonally stratified shelf sea. J Geophys Res 113:C12005 doi:10.1029/2007JC004531

> Pingree RD, Pennycuick L (1975) Transfer of heat, fresh water and nutrients through the seasonal thermocline. J Mar Biol Assoc UK 55:261-274

> Pingree RD, Holligan PM, Mardell GT, Head RN (1976) The influence of physical stability on spring, summer and autumn phytoplankton blooms in the Celtic Sea. J Mar Biol Assoc UK 56:845-873

> Pingree RD, Holligan PM, Mardell GT (1978) The effects of vertical stability on phytoplankton distributions in the summer on the northwest European Shelf. Deep-Sea Res 25:1011-1028

> Poulton AJ, Sanders R, Holligan PM, Stinchcombe MC, Adey TR, Brown L, Chamberlain K (2006) Phytoplankton mineralization in the tropical and subtropical Atlantic Ocean. Global Biogeochem Cycles 20:1-10

> Raven JA (1997) Phagotrophy in phototrophs. Limnol Oceanogr 42:198-203

Redfield AC (1934) On the proportions of organic derivatives in sea water and their relation to the composition of plankton. In: Daniel JR (ed) James Johnson memorial volume. Liverpool University Press, Liverpool, p 179-192

> Richardson K, Bo Pedersen F (1998) Estimation of new production in the North Sea: consequences for temporal and spatial variability of phytoplankton. ICES J Mar Sci 55:574-580

> Richardson K, Visser AW, Bo Pederson F (2000) Subsurface phytoplankton blooms fuel pelagic production in the North Sea. J Plankton Res 22:1663-1671

> Rippeth TR, Palmer MR, Simpson JH, Fisher NR, Sharples J (2005) Thermocline mixing in summer stratified continental shelf seas. Geophys Res Lett 32:L05602 doi:10. 1029/2004GL022104

> Robinson C, Tilstone GH, Rees AP, Smyth TJ and others (2009) Comparison of in vitro and in situ plankton production determinations. Aquat Microb Ecol 54:13-34

Rodhe J, Tett P, Wulff F (2006) The Baltic and North Seas: a regional review of some important physical-chemicalbiological interaction processes. In: Robinson AR, Brink K (eds) The sea. Vol 14B: the global coastal ocean: interdisciplinary regional studies and synthesis. Harvard University Press, Cambridge, MA, p 1033-1075

Scott BE, Sharples J, Ross ON, Wang J, Pierce GJ, Camphuysen CJ (2010) Sub-surface hotspots in shallow seas: fine-scale limited locations of top predator foraging habitat indicated by tidal mixing and sub-surface chlorophyll. Mar Ecol Prog Ser 408:207-226

Sharples J, Holligan P (2006) Interdisciplinary studies in the Celtic Seas. In: Robinson AR, Brink K (eds) The sea. Vol 14B: the global coastal ocean: interdisciplinary regional studies and synthesis. Harvard University Press, Cambridge, MA, p 1003-1031 
Sharples J, Moore CM, Rippeth TR, Holligan PM, Hydes DJ, Fisher NR, Simpson JH (2001a) Internal tide dissipation, mixing, and vertical nitrate flux at the shelf edge of NE New Zealand. J Geophys Res 106:14069-14081

Sharples J, Moore C, Abraham ER (2001b) Phytoplankton distribution and survival in the thermocline. Limnol Oceanogr 46:486-496

Sharples J, Ross ON, Scott BE, Greenstreet SPR, Fraser H (2006) Inter-annual variability in the timing of stratification and the spring bloom in the North-western North Sea. Cont Shelf Res 26:733-751

Sharples J, Tweddle JF, Green JAM, Palmer MR and others (2007) Spring-neap modulation of internal tide mixing and vertical nitrate flux at a shelf edge in summer. Limnol Oceanogr 52:1735-1747

Simpson JH, Hunter JR (1974) Fronts in the Irish Sea. Nature 250:404-406

Tassan S, Ferrari GM (1995) An alternative approach to absorption measurements of aquatic particles retained on filters. Limnol Oceanogr 40:1358-1368

Taylor AH, Harris JRW, Aiken J (1986) The interaction of physical and biological processes in a model of the vertical distribution of phytoplankton under stratification. Elsevier Oceanogr Ser 42:313-330

Tilstone GH, Figueiras FG, Fermin EG, Arbones B (1999) Significance of nanophytoplankton photosynthesis and primary production in a coastal upwelling system (Ria de Vigo, NW Spain). Mar Ecol Prog Ser 183:13-27

Tilstone GH, Figueiras FG, Lorenzo LM, Arbones B (2003) Phytoplankton composition, photosynthesis and primary production during different hydrographic conditions at

Editorial responsibility: Graham Savidge, Portaferry, UK the Northwest Iberian upwelling system. Mar Ecol Prog Ser 252:89-104

Tsunogai S, Watanabe S, Sato T (1999) Is there a 'continental shelf pump' for the absorption of atmospheric $\mathrm{CO}_{2}$ ? Tellus Ser B Chem Phys Meteorol 51:701-712

Tweddle JF (2007) Nutrient fluxes into the seasonal thermocline of the Celtic Sea. PhD thesis, University of Southampton

- Ward BA, Dutkiewicz S, Barton AD, Follows MJ (2011) Biophysical aspects of resource acquisition and competition in algal mixotrophs. Am Nat 178:98-112

> Wawrik B, Boling WB, Van Nostrand JD, Xie J, Zhou J, Bronk DA (2012) Assimilatory nitrate utilization by bacteria on the West Florida Shelf as determined by stable isotope probing and functional microarray analysis. FEMS Microbiol Ecol 79:400-411

- Weiss RF (1970) The solubility of nitrogen, oxygen and argon in water and seawater. Deep-Sea Res Oceanogr Abstr 17:721-735

> Welschmeyer NA (1994) Fluorometric analysis of chlorophyll $a$ in the presence of chlorophyll $b$ and pheopigments. Limnol Oceanogr 39:1985-1992

> Weston K, Fernand L, Mills DK, Delahunty R, Brown J (2005) Primary production in the deep chlorophyll maximum of the central North Sea. J Plankton Res 27:909-922

Williams PJB (1993) On the definition of plankton production terms. ICES J Mar Sci 197:9-19

Z Zubkov MV, Fuchs BM, Burkill PH, Amann R (2001) Comparison of cellular biomass and specific activities of dominant bacterioplankton groups in stratified waters of the Celtic Sea. Appl Environ Microbiol 67:5210-5218

Submitted: November 21, 2011; Accepted: May 22, 2012

Proofs received from author(s): August 15, 2012 